\title{
Agricultural activities and threat to fauna in Brazil: an analysis of the Red Book of Endangered Brazilian Fauna
}

\author{
Marcelo Marcelino de Oliveiraa ${ }^{13}$; Ronaldo Gonçalves Morato ${ }^{2,4}$; Rodrigo Silva Pinto Jorge ${ }^{1,5}$ \& Rogério Cunha de Paula ${ }^{2,6}$
}

1 Instituto Chico Mendes de Conservação da Biodiversidade (ICMBI0),

Centro Nacional de Avaliação da Biodiversidade e de Pesquisa e Conservação do Cerrado (CBC). Brasilia, DF, Brasil.

2 Instituto Chico Mendes de Conservação da Biodiversidade (ICMBI0),

Centro Nacional de Pesquisa e Conservação de Mamíferos Carnívoros (CENAP). Atibaia, SP, Brasil.

3 ORCID: http://orcid.org/0000-0002-1363-1210. E-mail: marcelo.marcelino@icmbio.gov.br

${ }^{4}$ ORCID: http://orcid.org/0000-0002-8304-9779. E-mail: ronaldo.morato@icmbio.gov.br

${ }^{5}$ ORCID: http://orcid.org/0000-0001-9876-4532. E-mail: rodrigo.jorge@icmbio.gov.br

${ }^{6}$ ORCID: http://orcid.org/0000-0003-1943-8320. E-mail: rogerio.paula@icmbio.gov.br

\begin{abstract}
The recent edition of the Red Book of Endangered Brazilian Fauna brings 1,173 threatened species, 86\% of them in terrestrial or freshwater environments. For these species, the main threat vector is agricultural activities that affect 519 species (51\%). This information brought by the Red Book is examined in-depth and its consistency is discussed in search of an objective view on the impacts of agriculture, its importance, how they affect the different groups of animals, the different biomes of the country, and the different types of habitats continental. Birds, fish, and invertebrates are the groups with the highest number of species threatened by agricultural activity, accounting for more than $70 \%$ of the species. Habitat loss is by far the biggest impact caused by the activity, affecting almost $90 \%$ of the species. However, there is a difference between the impact of agriculture and livestock. The work seeks to understand why livestock threatens a smaller number of species, although pastures occupy more than twice the area occupied by crops and forestry. The work brings an objective debate on the relationship between agricultural activities and the conservation of wild fauna in Brazil, without falling into the trap of the useless demonization of human activities, highlighting, instead, the need to define and implement strategies for the conservation of biodiversity in the midst the land use matrix itself, complementary to the conservation units, based on the best available information on the vulnerability of fauna to the impacts of this vector.
\end{abstract}

Keywords. Endangered Species; Biodiversity Conservation; Habitat Loss; Habitat Fragmentation; Land-use Change.

\section{INTRODUCTION}

The evaluation of the degree of threat to a species or ecosystem is a fundamental step in the process of biodiversity conservation. Since the 1950s, the International Union for Conservation of Nature (IUCN) has compiled lists of species at risk of extinction (Mace et al., 2008). Enhanced throughout these years, the IUCN Red List of Endangered Species (IUCN Red List) has become a powerful tool to catalyze biodiversity conservation actions and promote public policies for the protection of natural resources (IUCN, 2019a).

First published in 1968 (IBDF, 1968) and contemporary to the IUCN Red List, the Official List of Endangered Brazilian Fauna was later influenced by the IUCN, as in its third edition published in 1989 the IUCN criteria and categories were partially applied in its updating process (Machado,
2008), and widely used in the following review process in 2002 (Drummond \& Soares, 2008).

In the current editions published in 2014 (MMA, 2014a, b), not only did the IUCN assessment model serve as a basis for the review again but for the first time, the national lists started to incorporate the extinction risk categories of the Red List in its official text. For each edition of the official lists of the Brazilian Government, a corresponding scientific version was published, receiving in 2008 the name of the Red Book of Endangered Brazilian Fauna (Machado et al., 2008), in an unequivocal alignment with the evaluation IUCN's risk of extinction model.

The current edition of the Red Book of Endangered Brazilian Fauna (hereafter RBB; ICMBio, 2018a) brings an important innovation compared to previous editions. In addition to the complete list of all 12,254 species evaluated and information on the taxonomy, geographical distri- 


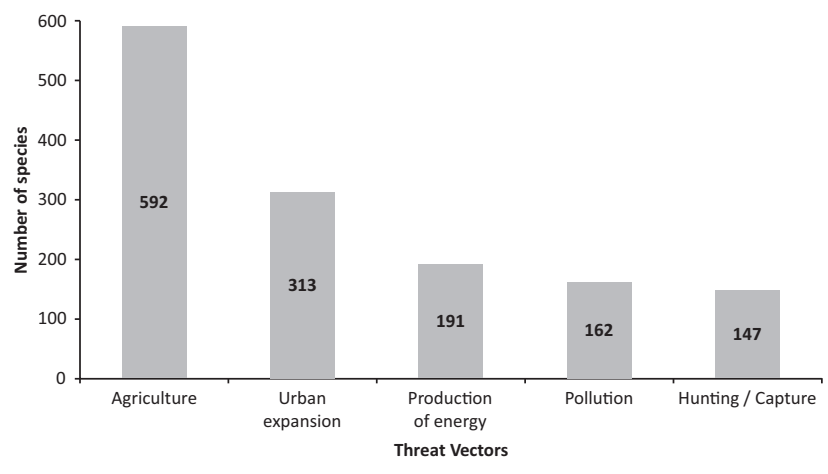

Figure 1. Continental species affected by the main threat vectors (ICMBio, 2018a).

bution, population, and threats of the 1,173 threatened species, there is an effort to identify the human activities that originate the threats. Although the information about the threat vectors, as these human activities are called, needs more precision, the vision that they provide about the conservation of biodiversity in Brazil is undoubtedly all-embracing. Not only do they disclose a much broader picture of threats to species, but also provides more objective perspectives for the formulation and negotiation of effective actions for their conservation.

Agricultural activities are identified by the RBB (ICMBio, 2018a) as the main vector of threats to species, followed by urban expansion by far and even more distant by the generation of hydraulic energy (Fig. 1). Agricultural activities prevail as the main threat vector in almost all Brazilian terrestrial biomes, except in the Amazon Biome, where these activities are surpassed by the generation of hydraulic energy by the narrow margin of a species. In most other terrestrial biomes, the number of species affected by threats from agricultural activities is more than twice as high than the others. From this perspective, this study explores the hypothesis that as a result of the novelty of threat vectors associated to endangered species, although there is a significant degree of inaccuracy in the information that associates agricultural activities with threats to species (which possibly should also occur in other activities), it is possible to construct a reasonable picture of the role of agricultural activities in the risk of fauna extinction and apply it to conservation. The impact of agricultural activities on the environment is a recurrent theme in several technical and scientific documents, either due to the occupation of the land surface and the consequent reduction and fragmentation of the habitat (EMBRAPA, 2018); due to habitat degradation caused by excessive water consumption (Rodrigues \& Irias, 2004); by the processes of soil erosion, compaction, and salination (Thomas et al., 2013); or by the use of pesticides and their effects on water (Oliveira-Filho \& Lima, 2002) and other environments. The relationship between agricultural activities and the risk of extinction brought by the RBB (ICMBio, 2018a) is supported by extensive bibliography, as well as by the perception and empirical knowledge of scientists that were applied to the evaluation process to assess the status of species. This makes the RBB, although with some limitations, a formidable source for exploring this and other issues regarding species conservation.

\section{METHODS}

In the review of the RBB (ICMBio, 2018a), we examined the descriptions of each species, mainly the reasons for its classification as threatened, the threats to which they are subject, and the preferred habitats. We identified and selected species with clear descriptions of threats associated with agricultural activities and, for this selection, we avoided any subjective interpretation of the descriptions and strictly observed what was described by the authors of the species accounts. Based on the selection of species, we sought to identify the type of impact resulting from agricultural activities and highlighted their relevance based on the number of species affected by them. Then, we compared the incidence of impacts between the main groups of fauna, considering all classes of vertebrates separately and all invertebrate phylla as a single group. We also compared the incidence of impacts between biomes, between the types of preferred habitats, and between the modalities of agricultural activities. The term "agricultural activities" adopted in this study included the set of activities that take advantage of the environment and its natural resources for plant and animal production destined for human subsistence, including agriculture, livestock, forestry, and aquaculture (EMBRAPA, 2018). Fisheries, although also part of this set, was not addressed in the study because it is treated in a separate context in the RBB (ICMBio, 2018a). The results are presented in absolute numbers, using percentages to highlight and compare the most relevant aspects.

\section{RESULTS}

We found 519 species with threat quotes related to agricultural activities (Table S1), 73 less than the number shown in Fig. 1. For 461 species, agricultural activities are considered the main source of the threat, with birds, invertebrates and fishes appearing as the groups most affected by these activities (Fig. 2). For 167 species, agricultural activities are the only source of threat: proportionally, amphibians and invertebrates are the groups with the highest number of impacted species, with $57 \%$ and $48 \%$ of their species affected, while mammals and

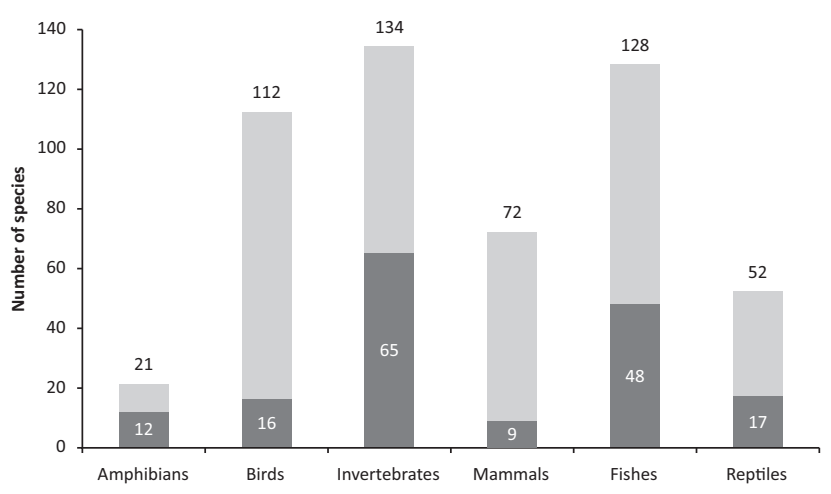

Figure 2. Number of species threatened, in each group, by agricultural activities. Highlight for the darker part of the columns with the number of species that has the only source of threat in agricultural activities. 


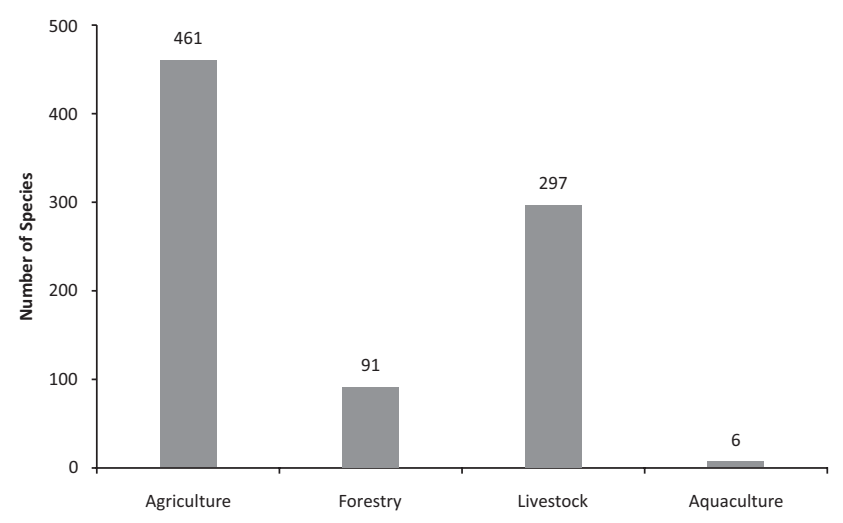

Figure 3. Number of species threatened by the different segments that make up agricultural activities.

birds (with $13 \%$ and $14 \%$ of species, respectively) are the ones with the lowest number (Fig. 2). Among the agricultural segments (Fig. 3), agriculture is the one with the highest number of citations (461), followed by livestock (297) and, silviculture (91).

Eleven forms of impact arising from agricultural activities were mentioned (Fig. 4). Habitat loss or reduction, as well as habitat fragmentation, are the most relevant impacts, affecting by far the largest number of species compared to other forms of impact that affect a much smaller number of species, the most relevant among them (agricultural pollution), not exceed $20 \%$ of the species threatened by the vector of agriculture. These other forms of impact are damage to the environment caused by plantations and the management of domestic livestock, leading to progressive degradation or loss of habitat quality. In addition to this group, there is direct loss of animals as a result of persecution and subsequent slaughter, in addition to diseases introduced by the cattle. For most species, agricultural activities cause more than one impact, only $37 \%$ are affected by one of these

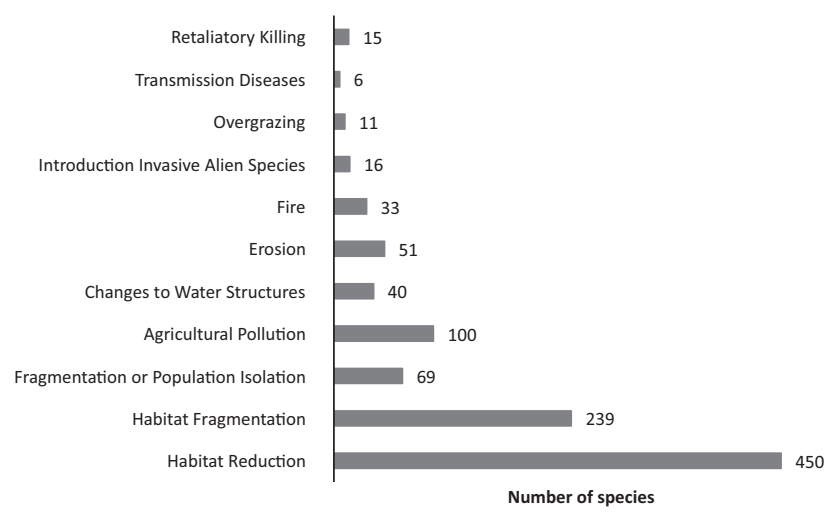

Figure 4. The impacts of agricultural activities and the number of species affected.

impacts: habitat reduction $(\mathrm{n}=155)$; agricultural pollution $(n=22)$; erosion $(n=13)$; retaliatory death $(n=2)$; introduction of invasive alien species and overgrazing (both with one species).

Habitat reduction is the most recurrent impact among the descriptions, affecting $87 \%$ of the species analyzed in this study, of which $91 \%$ have this type of impact as the main form of threat. Habitat fragmentation is cited for 239 species and identified as the main impact for $95 \%$ of them. Of the species cited as threatened by habitat fragmentation, the greatest number are invertebrates (Fig. 5), followed by mammals with the highest percentage (72\%). It is important to highlight that, in most descriptions, habitat fragmentation is mentioned in association with habitat reduction, not effectively discriminating between one effect and another; in addition, the isolation of populations appears as an additional impact on fragmentation.

According to Haddad et al. (2015) and Fletcher et al. (2018), isolation is one of the aspects of fragmentation and its citation in the RBB (ICMBio, 2018a) appears

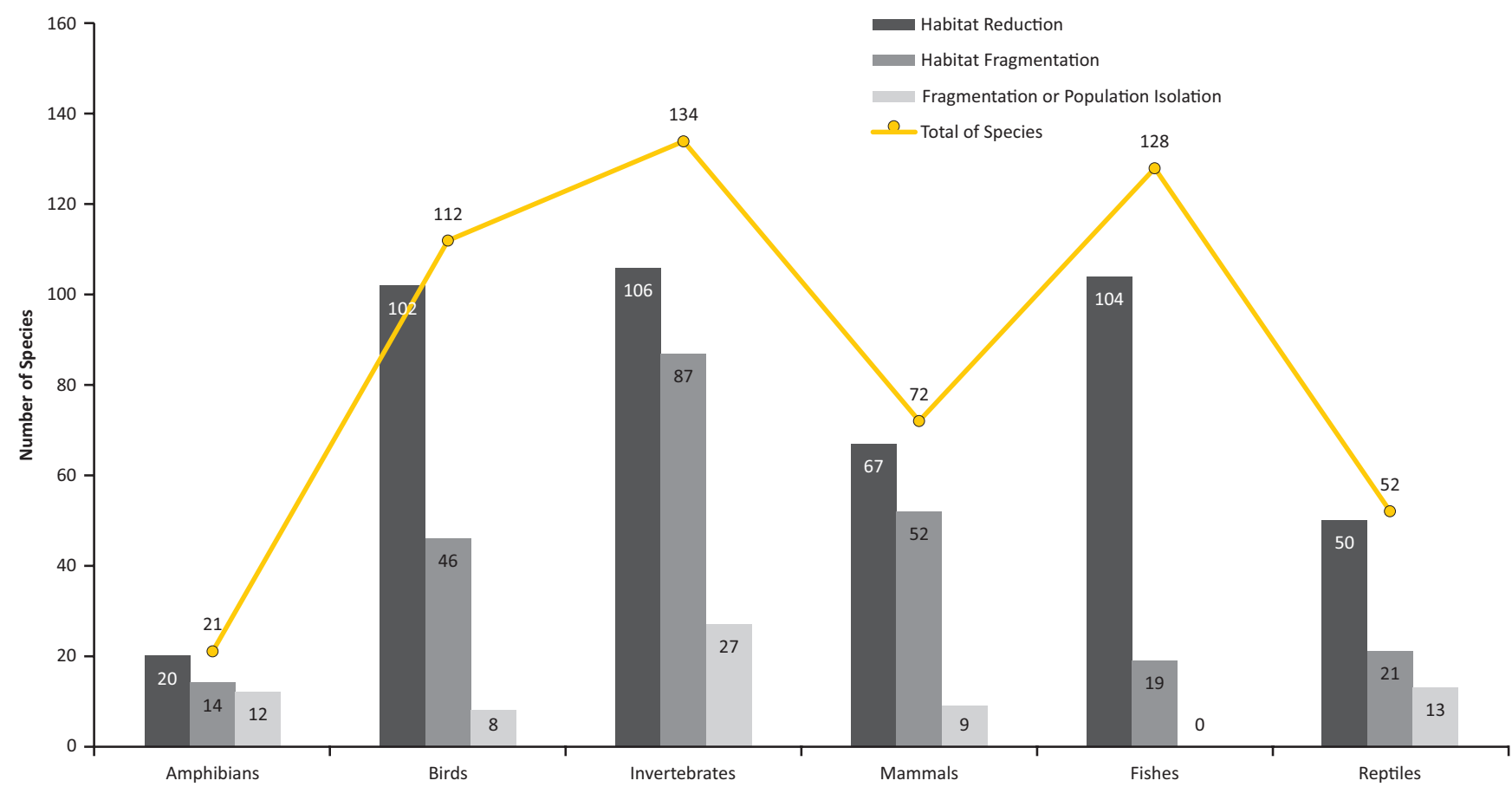

Figure 5. Number of species affected by isolation, in each group, compared to the number of species affected by habitat reduction and habitat fragmentation. 
mainly in species that occur in the Atlantic Forest biome $(n=53)$, representing $31 \%$ of species affected by habitat fragmentation in the biome. The Cerrado and Caatinga biomes have similar percentages of isolation citations, $28 \%$ and $32 \%$, respectively. In other biomes, this percentage is between $17 \%$ (Pampa) and 7\% (Pantanal). In the Amazon it reaches $11 \%$, with only three species affected. Population isolation is a type of impact that mainly affects invertebrates ( $n=27$ ), although amphibians have the highest percentage of citations (86\%) in species threatened by habitat fragmentation, suggesting that almost all amphibians in fragmented habitats have their populations isolated or disarticulated, as is the case of Bokermannohyla vulcaniae and Physalaemus soaresi, which have practically their entire population isolated in an area of forest fragments with approximately four $\mathrm{km}^{2}$ (Haddad et al., 2018a, b). The population isolation also affects a significant percentage of reptiles threatened by habitat fragmentation (62\%), with little representation for the rest of the groups: invertebrates (31\%); birds and mammals (17\%); reaching zero for fish.

Within habitat degradation, agricultural pollution is the one that emerges with the largest number of affected species $(n=100)$, representing much higher than the species impacted by erosion ( $n=51)$, by burning $(n=33)$, or by any other form of degradation responsible for the loss of habitat quality. Invertebrates are the group with the highest number of citations of threats of agricultural pollution ( $n=37)$, followed by fish $(n=34)$ and birds $(n=18)$. For most species of invertebrates and fish affected by agricultural pollution $(76 \%$ and $82 \%$, respectively), this form of impact is considered one of the main threats to the species. Unlike birds in which the impact of agricultural pollution is considered one of the main threats for only two species. This reflects the higher volume of descriptions of the impact of agricultural pollution on aquatic environments as one of the main threats: 49 of the 65 citations of aquatic pollution, against nine of the 29 citations of air pollution. Most of the invertebrates are aquatic, mainly decapods. Among the fish, the majority are species of rivulids (annual fish), of extremely restricted distribution, sometimes endemic to a single temporary pond (Hypsolebias auratus; Pavanelli et al., 2018a). The greatest predominance of citations of agricultural pollution in aquatic environments refers mainly to the possible toxic contamination of the environment by agrochemicals. The few mentions of water pollution by eutrophication of the environment are related to the carrying of livestock manure (Aegla brevipalma; Santos \& Bueno, 2018), and fertilizers associated with domestic effluents (Mergus octosetaceus; Silveira et al., 2018). In terrestrial environment, species affected by the application of herbicides, insecticides, and fungicides represent less than $30 \%$ of the threat citations for agricultural pollution, which predominantly occur through atmospheric propagation with the consequent contamination of individuals (Aleuron ypanemae; Camargo et al., 2018) or food on the ground surface (Circus cinereus; Dias \& Mauricio, 2018). Air pollution is mostly reported for birds $(n=15)$ and invertebrates (11), while descriptions of pollution from soil contamination are given to a small number of species that feed on decomposers, which are reduced by the action of fungicides (Gnamptogenys wilsoni; Delabie, 2018), or by species whose food, composed of ants and termites, are contaminated by insecticides (Myrmecophaga tridactyla; Miranda et al., 2018), in addition to a fossorial reptile and a cave pseudoscorpion that occur in an area with intense use of pesticides (Amphisbaena uroxena and Spelaeobochica allodentatus; Colli et al., 2018; Bichuette et al., 2018c).

Aquatic habitats, besides, being the most affected by agricultural pollution, are also strongly impacted by physical changes directly caused by agricultural activities, whether by direct interventions in water structures or by silting caused by soil erosion. The descriptions of the Red Book (ICMBio, 2018a) point out that 72 aquatic species are impacted by changes related to crop plantation or water use for irrigation. Silting resulting from soil erosion, caused mainly by the suppression of riparian vegetation, affects almost half of the 72 species $(n=35)$. Thirty-two species are threatened by dams, diversions of watercourses, and, mainly, drainage of flooded environments. For $94 \%$ of the 72 species, those threats are considered important. Aquatic invertebrates $(n=16)$ and, especially, fish ( $n=42)$ are the groups most affected. As with species threatened by water pollution, decapods and annual fish are most representative species in their respective groups.

Species impacted by physical changes in water structures reinforce the predominant role of agriculture as the source of the threat, compared to other types of agricultural activities. Changes in water structures caused by plantations affect $90 \%$ of the taxa, against $54 \%$ of species affected by water structures changes resulting from pasture management and only $13 \%$ of species impacted by changes promoted by forestry. The greatest impact of agriculture results from dams and drainages that affect 31 species, twice as many as those affected by the same water structure changes resulting from pasture management $(n=15)$.

Considering that irrigated agriculture (ANA, 2017) consumed $67 \%$ of the water in the country and that most or all the water extracted in irrigation does not return to the original water sources (Rodrigues \& Irias, 2004), it would be reasonable to expect a significant number of aquatic species affected by the exhaustion of water sources or lowering of the water table. However, those two threats are cited only for very few species (seven and two, respectively). Furthermore, the depletion of springs is not brought about in a clearly expressed way, but it is associated with other threats that mainly affect some fish of very restricted distribution (Pamphorichthys pertapeh; Pavanelli et al., 2018b). The depletion of the water table is a threat described objectively for two species of troglobial fish (Stygichthys typhlops and Trichomycterus dali; Bichuette et al., 2018a; Bichuette et al., 2018b).

More than half of the species threatened by erosion and changes in water structures $(n=43)$ are also threatened by agricultural pollution, mainly fish $(n=26)$ and invertebrates $(n=12)$, and to a lesser extent, birds $(n=5)$. 
These results involving fish and invertebrates suggest a possible correlation between these threats, perhaps the transport of pesticides associated with silting.

Erosion, changes in water structure and water pollution are cited as threats to cave species threatened by agricultural activities $(n=24)$, represented mainly by invertebrates $(n=16)$, in addition to fish $(n=8)$. Erosion due to soil exposure after the removal of natural vegetation is the most incident impact $(n=19)$, resulting in the silting of stretches of watercourses that pass through the interior of the cavities $(n=6)$. In addition to changes in the structure of the cavities, threats related to agricultural pollution were cited for a small group of species $(n=6)$, all involving toxic contamination, mostly aquatic species $(n=5)$.

Among the impacts of habitat degradation, the use of fire as an agricultural practice has little expression, being cited for 33 species, mostly birds $(n=19)$. It is hardly mentioned for the other groups, only five species of mammals and two species of reptiles. Among invertebrates, there are only seven species, although some studies report a decrease in invertebrate populations after burning (Redin et al., 2011).

\section{The intrinsic impacts on livestock}

For a set of 41 endangered species, the descriptions of the RBB (ICMBio, 2018a) present citations of other forms of impact that are intrinsic to livestock, although in some species they also appear associated with agriculture and aquaculture, in case of conflicts with farmers and the introduction of invasive alien species, respectively. The other impacts are represented by cattle overgrazing and the transmission of introduced diseases and are exclusive to livestock. In 16 citations, these impacts were considered among the main risk factors for species extinction, generally as a threat closely associated with habitat conversion.

The introduction of invasive alien species and the chasing and killing of predators are the threats that have the highest number of citations ( $n=16$ and $n=15$, respectively) among the 41 species of this set of threats. The threat posed by the introduction of exotic species refer to the replacement of the native grasslands and savannas with pastures of exotic grasses and the consequent change in habitat, except for two species of fish that are threatened by competition with introduced species; insectivorous and granivorous birds $(n=8)$ and herbivorous mammals $(n=6)$ are the groups most affected. Herbivorous mammals, all ungulates, are also the only group with species impacted by disease transmission.

Associated with the management of cattle and other herds, another impact is the preventive or retaliatory killing of predatory species: 15 species, mainly felines $(n=9)$, becoming an important threat to the jaguar (Panthera onca; Morato et al., 2018), puma (Puma concolor; Azevedo et al., 2018), and maned wolf (Chrysocyon brachyurus; Paula et al., 2018). This list also includes the crowned eagle (Urubitinga coronata; CEMAVE, 2018b), and the white-necked hawk (Amadonastur lacernulatus; CEMAVE, 2018a), which are the only citations of conflicts with birds involving cattle; all other conflicts $(n=3)$ are related to the foraging of parrots in corn, rice, and orange plantations (Amazona vinacea; Somenzari, 2018). Herd management is also associated with the impact of overgrazing that affects a small number of species $(n=11)$, the majority of birds ( $n=9$ ), in addition to one amphibian and one reptile species.

\section{DISCUSSION}

Food production is the human activity that most demands the use of land (EMBRAPA, 2018) largely promoting the conversion of habitats, one of the key factors for the decline of global biodiversity (Newbold et al., 2013, Haddad et al., 2015 and WWF, 2015). In Latin America, between the 1980s and the 1990s, areas converted for agricultural use increased by almost 50 million hectares (Gibbs et al., 2010), the majority on intact (55\%) or already degraded (28\%) forests. In Brazil, agricultural activities occupy about $30 \%$ of the territory (EMBRAPA, 2018), with an estimated direct impact on 519 species of native fauna, which represent $51 \%$ of the threatened species on the continent.

\section{Habitat fragmentation}

In most of the citations in the RBB (ICMBio, 2018a), habitat fragmentation is mentioned in association with habitat loss or reduction, not effectively discriminating one impact from the other. This view of fragmentation is mentioned by Tscharntke et al. (2012) for several studies, leading to the perception that these threats are linked or, as Fahrig $(2003,2013)$ and Fletcher et al. $(2018)$ agree, that concept of fragmentation of the habitat has been used as a simplified term to refer to the general process of changing the quantity and configuration of the habitat over time. However, for caution, when interpreting the use of the term in the descriptions of the Red Book (ICMBio, 2018a), this study preferred Hanski's (2015) understanding that fragmentation poses an additional risk to habitat loss.

Although some authors (Tscharntke et al., 2012; Fahrig, 2017; Fahrig et al., 2019) question the hypothesis that fragmentation per se (in addition to habitat loss) has a significant effect on biodiversity reduction, the number of species affected by fragmentation in the Atlantic Forest seems to support the contrary conclusion of Haddad et al. (2015), which advocates the significant role of habitat fragmentation in reducing biodiversity, as a result of its consistent and cumulative effects. The study by Haddad et al. (2015) highlights the wide reduction of the Atlantic Forest in the last three centuries, transformed into a landscape dominated by a complex matrix formed by urbanized areas, farming, and several other human activities, with scattered forest fragments, mostly with less than 1,000 ha. It is in this biome that most of the 519 
species threatened by the agricultural vector are concentrated (57\%), of which $58 \%$ are also affected by fragmentation. It is the highest percentage among all biomes, where possibly the cumulative effects of fragmentation are greater, compared to the Cerrado, the second biome in the number of threatened species (36\%), where habitat conversion is more recent and, perhaps because of this, the number of species affected by habitat fragmentation reaches the lowest level of $36 \%$ of threatened species. It is interesting to note that although most forests in the Amazon biome remain contiguous (Haddad et al., 2015), the percentage of threatened species affected by fragmentation (44\%) is higher than that of the Cerrado.

Population isolation due to habitat fragmentation, as recognized by the IUCN (2019b), as a rule, is the type of impact to which species whose adult stages are less efficient in long-distance dispersal are subject. This explains the highest percentage of amphibians in fragmented landscapes affected by isolation (86\%) from the other groups. Most of these amphibians (83\%) have an area of occurrence smaller than $2,000 \mathrm{~km}^{2}$ and for $58 \%$ the area of occurrence is less than half this size, evidencing their low dispersal capacity and, consequently, their greater vulnerability to habitat fragmentation. Not coincidentally, $83 \%$ of amphibians affected by isolation inhabit the Atlantic Forest and are restricted to forest environments.

\section{Habitat degradation}

Other impacts identified in the RBB descriptions (ICMBio, 2018a), namely habitat degradation, are described for 183 of the species threatened by agricultural activities, $42 \%$ of which are affected by more than one of these impacts. It is interesting to note that 52 species are affected only by habitat degradation.

However, most impacts related to habitat degradation have, so far, no scientific evidence, as the chemical contamination of wild animals. The RBB (ICMBio, 2018a) mentions this type of impact for 100 species, principally invertebrates (37\%), fishes (34\%), and birds (18\%), but only three articles support this statement, focusing on invertebrates (Brown-Jr, 1993; Santos et al., 2012) and mammals (Rosas, 1994). The impacts by pesticides on RBB (ICMBio, 2018a) are mainly based on the suspected and generalization of the authors and, are likely influenced by the high consumption of pesticides in Brazil, especially in the large soy plantations (Pignati et al., 2017). Faita et al. (2020) found, in the laboratory essays, that these herbicides based on glyphosate, can affect the survival of bee colonies when used in large quantities. It is curious to note, however, that the RBB (ICMBio, 2018a) does not mention the impact of pesticides on threatened bee species, despite this being the group of invertebrates likely to be most affected. The RBB (ICMBio, 2018a) also provides little information on the impact of invasive alien species introduced by agricultural activities. Despite the importance of this type of impact for species in altered landscapes (Fischer \& Lindenmayer, 2007), only 16 affected species are mentioned by the Red
Book (ICMBio, 2018a), mainly birds (56\%). This little information available probably reflects the information gaps on the subject in the country, pointed out by Zenni et al. (2016). Likewise, there is little information on the impact of fire, which is an agricultural practice widely used in the country to prepare the soil, to suppress vegetation in the forest (Costa et al., 2011), to remove crop residues, to eliminate pests and weeds and to fertilize the soil (Korontzi et al., 2006). Costa \& Rodrigues (2015) mention that the high frequency of fire in natural pastures promotes the elimination of sensitive plant species, reducing the floristic diversity and causing changes in habitat. This type of change in open environments possibly affects most bird species (63\%), the group with the largest number of species impacted by fire, as well as reptiles. In other groups, most species are possibly impacted by fires in forest environments (57\% of invertebrates and $80 \%$ of mammals), associated with the installation of crops in the process of advancing the agricultural frontier, mainly in the Amazon (Cebus kaapori; Fialho et al., 2018). It is interesting to note that the RBB (ICMBio, 2018a) does not mention amphibian species impacted by fire, although scientific literature reports a reduction in the richness and abundance of anuran species as a result of this type of impact (Ribeiro et al., 2020).

\section{The impacts of overgrazing and the relationship between cattle and wild animals}

In addition to the impact described for fire, excessive grazing of cattle also promotes the exclusion of native plant species (Dias-Filho \& Ferreira, 2009), as it hinders their regeneration. Birds are the species most affected by this type of impact ( $82 \%)$, causing the degradation of the breeding area (Sporophila palustris; Dias \& Malaco, 2018) and even the possible crushing of nests and young (Xanthopsar flavus and Xolmis dominicanus; Dias, 2018a, b). Virtually all species impacted by overgrazing, including reptiles and amphibians, are in open areas, inhabiting fields $(n=4)$ or humid areas $(n=7)$, where herbaceous and shrubby vegetation predominates. Livestock management is also strongly implicated in the impacts represented by conflicts between natural predators and farmers. Although conflicts involve a very small number of species, they are important impacts that affect large cats (Panthera onca; Morato et al., 2018). The conflicts, as a rule, reflect the reduction and degradation of the habitat that leads to the reduction of natural prey, or the excessive availability of herds, due to the inadequate management of cattle that facilitates the attack of large carnivores (Paula \& Boulhosa, 2015). These conflicts have a significant impact on the populations of carnivorous mammals (Balbuena-Serrano et al., 2020), species that generally occupy the top of the food chain in all terrestrial ecosystems. In the case of felines, all species threatened by the agricultural vector are affected by conflicts with farmers. The cattle herd is also a way of introducing diseases that affect practically all ungulates threatened by agricultural activity, except only the small 
red brocket deer (Mazama bororo). This type of impact, although it has been described for species of wide occurrence (Tapirus terrestris; Medici et al., 2018), seems to be concentrated in the species that occur in the Cerrado and Pantanal biomes, where there is a great livestock activity, mainly in the Pantanal, where livestock represents the main economic activity in the region.

\section{The possible relationship between habitat and the greatest impact of agriculture}

It is interesting to note that livestock is the vector with the greatest diversity of impacts, covering the entire set listed in Fig. 4, including some that are entirely exclusive to it: transmission diseases; and overgrazing. Still, it is the activity with the smallest number of species affected, when compared to agriculture. Crops, along with planted forests, occupy only $9 \%$ of the territory (EMBRAPA, 2018), but impacts $89 \%$ of the species threatened by the agricultural vector, while livestock, which occupies $21 \%$ of the territory, impacts only $57 \%$ of species (Fig. 3). This difference is practically repeated in the number of species affected by habitat reduction and fragmentation. Among terrestrial species with available information on habitat preference, it is clear that, except for reptiles, there is a greater predominance of species that inhabit forest environments (Fig. 6). These figures draw attention to the possibility that species of forest habitats may be more affected by the impacts of agricultural activities than species of open habitats, regardless of the type of activity. For birds, this assumption is supported by the results obtained by Newbold et al. (2013), which point out that species dependent on forest habitat suffer more adverse effects from habitat loss or degradation than species with a preference for more open habitats. Likewise, Prescott et al. (2016) found no significant differences between the Colombian Llanos forest habitats modified by pastures and palm oil crops in terms of richness and phylogenetic distance between individuals in the bird community. Similarly, Boron et al. (2019) did not perceive evident effects on mammals in these environments.

Apparently, it is not the type of agricultural activity that provides the greater or lesser number of impacted

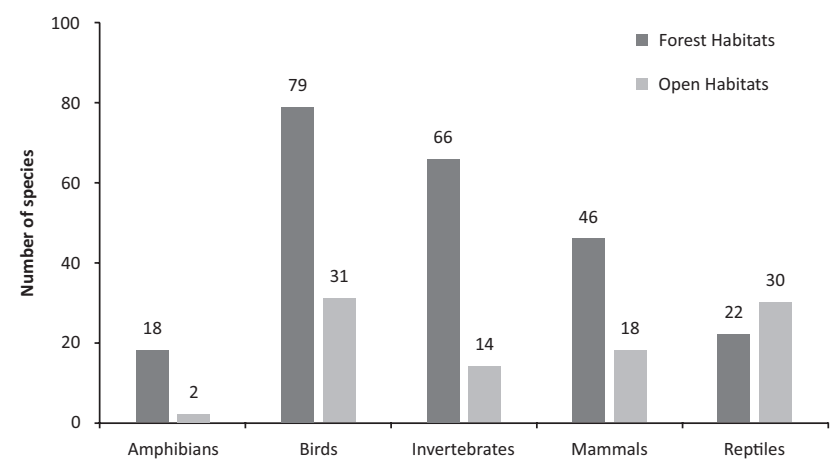

Figure 6. Number of terrestrial species affected by agricultural activities with information available on preference for forest habitats or open habitats. species, but the type of habitat that is suppressed for its installation. Converting open habitats for agricultural use affects fewer species compared to converting forest habitats. Forest habitats are recognized for a greater diversity of species (Ashton, 1989; Wilson, 1997), therefore, a greater number of species threatened by their suppression is expected, mainly in the Atlantic Forest, where the extensive suppression of habitats began in the century $\mathrm{XVI}$. This scenario explains the smaller number of species impacted by livestock which, despite occupying an area $60 \%$ larger than agriculture, has a soil occupation matrix with a higher percentage of open habitats in the Pantanal and Cerrado, reaching 38\% of the native pastures in its composition (EMBRAPA, 2018). Besides, the RBB (ICMBio, 2018a) includes descriptions of species of open habitats that apparently are tolerant to the changes caused by livestock, some of which even benefited from the activity, such as the buff-breasted sandpiper (Calidris subruficollis; Serafini, 2018), apparently favored by the overgrazing in the natural fields that creates a suitable environment for your shelter. An even more peculiar case occurs in the high-altitude fields of the Atlantic Forest in southeastern and southern Brazil, mostly converted to pastures, where an endangered species of scarab beetle (Pedaridium hirsutum; Vaz-de-Mello \& Nunes, 2018) has a diet based on horse feces. This diet is probably a change from your original diet that should have been based on tapir feces, animals that are no longer common in the region. Interestingly, the only two areas where the species is currently registered became protected areas and the presence of horses in these areas became incompatible. Without the presence of horses, the scarab beetle's main food source may have ceased in the two areas where there is the current record of the species, and this fact seems to contribute to the threat to the species.

\section{Conservation strategies}

In the RBB (ICMBio, 2018a), among the species of mammals and reptiles threatened by the agricultural vector, there are 41 mammals and eight reptiles with citations of movement of individuals in anthropized environments, suggesting some degree of tolerance to altered habitats, against 11 species of mammals and 14 reptiles described as intolerant to habitat change. For another 18 species of mammals and 30 of reptiles, no information is available. Although protected areas are an essential part of any conservation strategy and some authors defend their distribution more coincident with hotspots of endemism (Dalapicolla et al., 2021) or the lands that in the future will house endemic threatened species (Gonçalves-Souza et al., 2020), it is becoming increasingly clear that they will not be enough to maintain species and biodiversity conservation will need to extend beyond them (Fischer et al., 2006; Magioli et al., 2021). This vision highlights the importance of other instruments for the conservation of biodiversity, in addition to protected areas, mainly the strategic planning of actions for the conservation of species, involving 
the entire range of organizations and individuals interested in species and their habitat (IUCN, 2019a). Until 2017, Brazil had 645 threatened species (55\% of the current list) as targets of conservation plans (ICMBio, 2018a). And in 2018, ICMBio published a new type of plan (ICMBio, 2018b), aimed mainly at mitigating the impacts of roads and railways on 462 species of fauna, in addition to other 1,943 species of plants, involving not only threatened species, but also taxa with very restricted distribution (under $5,000 \mathrm{~km}^{2}$ ). This new modality of planning brought an objective vision of species survival in the midst of economic activity, indicating areas for the development of the activity with less risk of loss of biodiversity, as well as areas suitable for the adoption of compensatory measures, in addition to a set of measures to prevent or mitigate impacts. It is an instrument that optimizes the use of available knowledge about species, and modeling tools, to build objective scenarios of compatibility between economic activity and species conservation, which, transported to agrosystems, bring a perspective of biodiversity conservation close to Daily's (2001) view on the future of species survival.

\section{CONCLUDING REMARKS}

The occupation of the landscape in Brazil by crops and pastures impacts 519 endangered species of native fauna, most of which are affected by habitat reduction, associated with fragmentation. In addition to these impacts, the RBB (ICMBio, 2018a) mentions other types of impacts, eight in total, mainly related to habitat degradation. These impacts, however, are putative and have no scientific basis, which urge the need for new research programs, not only to verify whether these impacts occur but to understand how they affect species, to allow the identification of measures that can prevent or mitigate its effects. Mainly on agricultural pollution, which among the impacts of degradation is the one with the greatest number of affected species.

Likewise, it is important to seek to better understand the reason for the greater number of species threatened by agriculture compared to livestock, which occupies a $60 \%$ larger territory. We suspect that the land occupation matrix by livestock uses a higher percentage of open habitats, including natural pastures, which leads to considering the possibility that species of forest habitats are more affected than species of open habitats. Understanding this difference, as well as how species are affected and how they respond to changes, is essential for the intelligent management of the agricultural occupation matrix, which reduces its impacts on the environment and provides conditions for the survival of species and the maintenance of the ecosystem service. This is an important issue because we believe that the future of biodiversity conservation will depend on conservation strategies complementary to protected areas. Strategies that should be implemented in the land-use matrix itself, making economic production compatible with the conservation of species and ecosystems.

\section{AUTHORS' CONTRIBUTIONS}

MMO: Compilation of information from the Red Book of Endangered Brazilian Fauna, writing, review, and editing. RGM and RSPJ: Writing and review. RCP: Review. All the authors actively participated in the discussion of the results and approved the final version of the document.

\section{REFERENCES}

Agência Nacional de Águas e Saneamento Básico (ANA). 2017. Conjuntura dos recursos hídricos no Brasil 2017: relatório pleno. Brasília, ANA.

Ashton, P.S. 1989. Species richness in tropical forests. In: Holm-Nielsen, L.B.; Nielsen, I.C. \& Balslev, H. (Eds.). Tropical forests: botanical dynamics, speciation and diversity. Padstow, Academic Press. p. 239-251.

Azevedo, F.C.; Lemos, F.G.; Almeida, L.B.; Campos, C.B.; Beisiegel, B.M.; Paula, R.C.; Crawshaw-Jr., P.G.; Ferraz, K.M.P.M.B. \& Oliveira, T.G. 2018. Puma concolor (Linnaeus, 1771). In: ICMBio (Ed.). Livro Vermelho da Fauna Brasileira Ameaçada de Extinção: Volume ll - Mamíferos. Brasília, ICMBio. p. 358-366.

Balbuena-Serrano, Á.; Zarco-Gonzalez, M.M.; Monroy-Vilchis, 0.; Morato, R.G. \& Paula, R.C. 2020. Hotspots of livestock depredation by pumas and jaguars in Brazil: a biome-scale analysis. Animal Conservation, 24(2): 181-193. DOI

Bichuette, M.E.; Gallão, J.E.; Trajano, E.; Pavanelli, C.S.; Bock, C.L.; Oliveira, C.; Di Dario, F.; Vieira, F.; Neo, F.A.; Ingenito, L.F.S.; Silva, L.F.D.; Mehanna, M.N.; Albornoz, P.C.L.; Buckup, P.A.; Castro, R.M.C.; Rocha, R.C.G.A.; Reis, R.E.; Santos-Jr., S. \& Ramos, T.P.A. 2018a. Stygichthys typhlops Brittan \& Böhlke, 1965. In: ICMBio (Ed.). Livro Vermelho da Fauna Brasileira Ameaçada de Extinção: Volume VI - Peixes. Brasília, ICMBio. p. 160-163.

Bichuette, M.E.; Gallão, J.E.; Trajano, E.; Pavanelli, C.S.; Bock, C.L.; Oliveira, C.; Di Dario, F.; Vieira, F.; Neo, F.A.; Ingenito, L.F.S.; Silva, L.F.D.; Mehanna, M.N.; Albornoz, P.C.L.; Buckup, P.A.; Rocha, R.C.G.A.; Reis, R.E.; Santos-Jr., S. \& Ramos, T.P.A. 2018b. Trichomycterus dali Rizzato, Costa, Trajano \& Bichuette, 2011. In: ICMBio (Ed.). Livro Vermelho da Fauna Brasileira Ameaçada de Extinção: Volume VI - Peixes. Brasília, ICMBio. p. 283-285.

Bichuette, M.E.; von Schimonsky, D.M.; Gallão, J.E. \& Andrade, R. $2018 c$. Spelaeobochica allodentatus Mahnert, 2001. In: ICMBio (Ed.). Livro Vermelho da Fauna Brasileira Ameaçada de Extinção: Volume VII Invertebrados. Brasília, ICMBio. p. 549-550.

Boron, V.; Deere, N.J.; Xofis, P.; Link, A.; Quiñones-Guerrero, A.; Payan, E. \& Tzanopoulos, J. 2019. Richeness, diversity, and factors influencing occupancy of mammal communities across human-modified landscapes in Colombia. Biological Conservation, 232: 108-116.

Brown-Jr.; K.S. 1993. Theclinae endemic to the Cerrado vegetation (central Brazil). In: New, T.R. (Ed.). Conservation biology of Lycaenidae. Occasional Paper of the IUCN Species Survival Commission, 8. Gland, IUCN. p. 152.

Camargo, A.J.A.; Correa, D.C.V.; Amorim, F.W.; Bizarro, J.M.S. \& Camargo, W.R.F. 2018. Aleuron ypanemae (Boisduval, 1875). In: ICMBio (Ed.). Livro Vermelho da Fauna Brasileira Ameaçada de Extinção: Volume VII Invertebrados. Brasília, ICMBio. p. 55-56.

Centro Nacional de Pesquisa e Conservação das Aves Silvestres (CEMAVE). 2018a. Amadonastur lacernulatus (Temminck, 1827). In: ICMBio (Ed.). Livro Vermelho da Fauna Brasileira Ameaçada de Extinção: Volume III Aves. Brasília, ICMBio. p. 115-117.

Centro Nacional de Pesquisa e Conservação das Aves Silvestres (CEMAVE). 2018b. Urubitinga coronata Sclater, 1878. In: ICMBio (Ed.). Livro Vermelho da Fauna Brasileira Ameaçada de Extinção: Volume III - Aves. Brasília, ICMBio. p. 118-121. 
Colli, G.R.; Fenker, J.; Tedeschi, L.; Bataus, Y.S.L.; Uhlig, V.M.; Silveira, A.L.; Rocha, C.F.D.; Nogueira, C.C.; Werneck, F.P.; Moura, G.J.B.; Winck, G.R.; Kiefer, M.C.; Freitas, M.A.; Ribeiro-Jr., M.A.; Hoogmoed, M.S.; Tinoco, M.S.; Valadão, R.M.; Vieira, R.C.; Maciel, R.P.; Faria, R.G.; Recoder, R.; Ávila, R.W.; Silva, S.T.; Ribeiro, S.L.B. \& Pires, C.S.A. 2018. Amphisbaena uroxena Mott, Rodrigues, Freitas \& Silva, 2008. In: ICMBio (Ed.). Livro Vermelho da Fauna Brasileira Ameaçada de Extinção: Volume IV - Répteis. Brasília, ICMBio. p. 147-148.

Costa, M.R.G.F.; Cândido, M.J.D.; Carneiro, M.S.S.; Neto, L.B.M.; Magalhães, J.A. \& Costa, N.L. 2011. Uso do fogo em pastagens naturais. Publicações em Medicina Veterinária e Zootecnia, 5: 1050.

Costa, Y.T. \& Rodrigues, S.C. 2015. Efeito do Fogo Sobre Vegetação e Solo a partir de Estudo Experimental em Ambiente de Cerrado. Revista do Departamento de Geografia - USP, 30: 149-165.

Daily, G.C. 2001. Ecological forecasts. Nature, 411: 245.

Dalapicolla, J.; Abreu, E.F.; Prado, J.R.; Chiquito, E.A.; Roth, P.R.O.; Brennand, P.G.G.; Pavan, A.C.O.; Pereira, A.; Mendes, F.R.; Alvarez, M.R.V.; Rios, E.0.; Cassano, C.R.; Miretzki, M.; Vélez, F.; Sevá, A.P.; Percequillo, A.R. \& Bovendorp, R.S. 2021. Areas of endemism of small mammals are underprotected in the Atlantic Forest. Journal of Mammalogy, gyab073. DOI

Delabie, J.H.C. 2018. Gnamptogenys wilsoni Lattke, 2007. In: ICMBio (Ed.). Livro Vermelho da Fauna Brasileira Ameaçada de Extinção: Volume VII Invertebrados. Brasília, ICMBio. p. 206-207.

Dias, R.A. 2018a. Xanthopsar flavus (Gmelin, 1788). In: ICMBio (Ed.). Livro Vermelho da Fauna Brasileira Ameaçada de Extinção: Volume III - Aves. Brasília, ICMBio. p. 569-571.

Dias, R.A. 2018b. Xolmis dominicanus (Vieillot, 1823). In: ICMBio (Ed.). Livro Vermelho da Fauna Brasileira Ameaçada de Extinção: Volume III - Aves. Brasília, ICMBio. p. 548-551.

Dias, R.A. \& Malaco, G. 2018. Sporophila palustris (Barrows, 1883). In: ICMBio (Ed.). Livro Vermelho da Fauna Brasileira Ameaçada de Extinção: Volume III - Aves. Brasília, ICMBio. p. 604-607.

Dias, R.A. \& Mauricio, G.N. 2018. Circus cinereus Vieillot, 1816. In: ICMBio (Ed.). Livro Vermelho da Fauna Brasileira Ameaçada de Extinção: Volume III Aves. Brasília, ICMBio. p. 112-115.

Dias-Filho, M.B. \& Ferreira, J.N. 2009. 0 Pastejo e a Biodiversidade da Pastagem. Documentos - EMBRAPA Amazônia Oriental, 355: 9-46.

Drummond, G.M. \& Soares, C. 2008. Metodologia de Revisão da Lista. In: Machado, A.B.M.; Drummond, G.M. \& Paglia, A.P. (Eds.). Livro Vermelho da Fauna Brasileira Ameaçada de Extinção. Brasília, MMA; Belo Horizonte, Fundação Biodiversitas. p. 43-62.

Empresa Brasileira de Pesquisa Agropecuária (EMBRAPA). 2018. Visão 2030:0 futuro da agricultura brasileira. Brasília: EMBRAPA.

Fahrig, L. 2003. Effects of Habitat Fragmentation on Biodiversity. Annual Review of Ecology, Evolution, and Systematics, 34: 487-515.

Fahrig, L. 2013. Rethinking patch size and isolation effects: the habitat amount hypothesis. Journal of Biogeography, 40: 1649-1663.

Fahrig, L. 2017. Ecological Responses to Habitat Fragmentation Per Se. Annual Review of Ecology, Evolution, and Systematics, 48: 1-23.

Fahrig, L.; Arroyo-Rodríguez, V.; Bennett, J.R.; Boucher-Lalonde, V.; Gazetta, E.; Currie, D.J.; Eigenbrod, F.; Ford, A.T.; Harrison, S.P.; Jaeger, J.A.G.; Koper, N.; Martin, A.E.; Martin, J.L.; Metzger, J.P.; Morrison, P.; Rhodes, J.R.; Saunders, D.A.; Simberloff, D.; Smith, A.C.; Tischendorf, L.; Vellend, M. \& Watling, J.I. 2019. Is habitat fragmentation bad for biodiversity? Biological Conservation, 230: 179-186.

Faita, M.R.; Cardozo, M.M.; Amandio, D.T.T.; Orth, A.I. \& Nodari, R.0. 2020. Glyphosate-based herbicides and Nosema sp. microsporidia reduce honey bee (Apis mellifera L.) survivability under laboratory conditions. Journal of Apicultural Research, 59(4): 332-342. D0I
Fialho, M.S.; Moura, E.F.; Ravetta, A.L.; Laroque, P.O. \& Queiroz, H.L. 2018. Cebus kaapori Queiroz, 1992. In: ICMBio (Ed.). Livro Vermelho da Fauna Brasileira Ameaçada de Extinção: Volume II - Mamíferos. Brasília, ICMBio. p. 253-259.

Fischer, J. \& Lindenmayer, D.B. 2007. Landscape modification and habitat fragmentation: a synthesis. Global Ecology and Biogeograph, 16:265-280.

Fischer, J.; Lindenmayer, D.B. \& Manning, A.D. 2006. Biodiversity, ecosystem function, and resilience: ten guiding principles for commodity production landscapes. Frontiers in Ecology and the Environment, 4: 80-86.

Fletcher, R.J.; Didham, R.K.; Banks-Leite, C.; Carlow, J.; Ewers, R.M.; Rosindell, J.; Holt, R.D.; Gonzalez, A.; Pardini, R.; Damschen, E.I.; Melo, F.P.L.; Ries, L.; Prevedello, J.A.; Tscharntke, T.; Laurence, W.F.; Lovejoy, T. \& Haddad, N.M. 2018. Is habitat fragmentation good for biodiversity? Biological Conservation, 226: 9-15.

Gibbs, H.K.; Ruesch, A.S.; Achard, F.; Clayton, M.K.; Holmgren, P.; Ramankutty, N. \& Foley, J.A. 2010. Tropical forests were the primary sources of new agricultural land in the 1980s and 1990s. Proceedings of the National Academy of Sciences of the United States of America, 107(38): 1632-1637.

Gonçalves-Souza, D.; Verburg, P.H. \& Dobrovolski, R. 2020. Habitat loss, extinction predictability and conservation efforts in the terrestrial ecoregions. Biological Conservation, 246(108579).

Haddad, C.F.B.; Segalla, M.V.; Bataus, Y.S.L.; Uhlig, V.M.; Batista, F.R.Q.; Garda, A.; Hudson, A.A.; Cruz, C.A.G.; Strüssmann, C.; Brasileiro, C.A.; Silvano, D.L.; Nomura, F.; Pinto, H.B.A.; Amaral, I.B.; Gasparini, J.L.R.; Lima, L.P.; Martins, M.R.C.; Hoogmoed, M.S.; Colombo, P.; Valdujo, P.H.; Garcia, P.C.A.; Feio, R.N.; Brandão, R.A.; Bastos, R.P. \& Carasmachi, U. 2018a. Bokermannohyla vulcaniae (Vasconcelos \& Giaretta, 2005). In: ICMBio (Ed.). Livro Vermelho da Fauna Brasileira Ameaçada de Extinção: Volume V - Anfibios. Brasília, ICMBio. p. 64-66.

Haddad, C.F.B.; Segalla, M.V.; Bataus, Y.S.L.; Uhlig, V.M.; Batista, F.R.Q.; Garda, A.; Hudson, A.A.; Cruz, C.A.G.; Strüssmann, C.; Brasileiro, C.A.; Silvano, D.L.; Nomura, F.; Pinto, H.B.A.; Amaral, I.B.; Gasparini, J.L.R.; Lima, L.P.; Martins, M.R.C.; Hoogmoed, M.S.; Colombo, P.; Valdujo, P.H.; Garcia, P.C.A.; Feio, R.N.; Brandão, R.A.; Bastos, R.P. \& Carasmachi, U. 2018b. Physalaemus soaresi Izecksohn, 1965. In: ICMBio (Ed.). Livro Vermelho da Fauna Brasileira Ameaçada de Extinção: Volume V - Anfibios. Brasília, ICMBio. p. 100-102.

Haddad, N.M.; Brudvig, L.A.; Clobert, J.; Davies, K.F.; Gonzalez, A.; Holt, R.D.; Lovejoy, T.E.; Sexton, J.0.; Austin, M.P.; Collins, C.D.; Cook, W.M.; Damschen, E.I.; Ewers, R.M.; Foster, B.L.; Jenkins, C.N.; King, A.J.; Laurance, W.F.; Levey, D.J.; Margules, C.R.; Melbourne, B.A.; Nicholls, A.0.; Orrock, J.L.; Song, D.X. \& Townshend, J.R. 2015. Habitat fragmentation and its lasting impact on Earth's ecosystems. Science Advances, 1: e1500052.

Hanski, I. 2015. Habitat fragmentation and species richness. Journal of Biogeography, 42(5): 989-993.

Instituto Brasileiro de Desenvolvimento Florestal (IBDF). 1968. Portaria № 303, de 29 de maio de 1968. Available: https://www.ibama.gov.br/ sophia/cnia/legislacao/IBDF/PT0303-290568.PDF. Access: 05/11/2020.

Instituto Chico Mendes de Conservação da Biodiversidade (ICMBio). 2018a. Livro Vermelho da Fauna Brasileira Ameaçada de Extinção. ICMBio, Brasília.

Instituto Chico Mendes de Conservação da Biodiversidade (ICMBio). 2018b. Plano de Redução de Impacto de Infraestruturas Viárias Terrestres sobre a Biodiversidade - PRIM-IVT. Available: https://www.icmbio.gov.br/portal/ faunabrasileira/planos-de-reducao-de-impacto. Access: 17/03/2021.

International Union for Conservation of Nature and Natural Resources (IUCN). 2019a. The IUCN Red List of Threatened Species. Version 2019-2. Available: http://www.iucnredlist.org. Access: 23/11/2020.

International Union for Conservation of Nature and Natural Resources (IUCN). 2019b. Guidelines for Using the IUCNRed List Categories and Criteria. Version 14. 
Prepared by the Standards and Petitions Committee. Availlable: http://www. iucnredlist.org/documents/RedListGuidelines.pdf. Access: 19/08/2021.

Korontzi, S.; McCarty, J.; Loboda, T.; Kumar, S. \& Justice, C. 2006. Global distribution of agricultural fires in croplands from 3 years of Moderate Resolution Imaging Spectroradiometer (MODIS) data. Global Biogeochemical Cycles, 20(2): GB2021.

Mace, G.M.; Collar, N.J.; Gaston, K.J.; Hilton-Taylor, G.; Akçakaya, H.R.; LeaderWilliams, N.; Milner-Gulland, E.J. \& Stuart, S.N. 2008. Quantification of extinction risk: IUCN's system for classifying threatened species. Conservation Biology, 22(6): 1424-1442.

Machado, A.B.M. 2008. Listas de Espécies da Fauna Brasileira Ameaçadas de Extinção: Aspectos Históricos e Comparativos. In: Machado et al. (Eds.). Livro Vermelho da Fauna Brasileira Ameaçada de Extinção. Brasília, Ministério do Meio Ambiente. p. 91-110.

Machado, A.B.M.; Drummond, G.M. \& Paglia, A.P. (Eds.). 2008. Livro Vermelho da Fauna Brasileira Ameaçada de Extinção. Brasília, Ministério do Meio Ambiente.

Machado, A.B.M; Drummond, G.M \& Paglia, A.P. (Eds.). 2008. Livro Vermelho da Fauna Brasileira Ameaçada de Extinção. Brasília, Ministério do Meio Ambiente.

Magioli, M.; Rios, E.; Benchimol, M.; Casanova, D.C.; Ferreira, A.S.; Rocha, J.; Melo, F.R.; Dias, M.P.; Nareizi, G.; Crepaldi, M.0.; Medes, L.A.M.; Nobre, R.A.; Chiarello, A.G.; García-Olaechea, A.; Nobre, A.B.; Devids, A.C.; Cassano, C.R.; Koike, C.V.; São Bernardo, C.S.; Homem, D.H.; Ferraz, D.S.; Abreu, D.L.; Cazetta, E.; Lima, E.F.; Bonfim, F.C.G.; Lima, F.; Prado, H.A.; Santos, H.G.; Nodari, J.Z.; Giovanelli, J.G.R.; Nery, M.S.; Faria, M.B.; Ferreira, P.C.R.; Gomes, P.S.; Rodarte, R.; Borges, R.; Zuccolotto, T.F.S.; Sarcinelli, T.S.; Endo, W.; Matsuda, Y.; Camargos, V.L. \& Morato, R.G. 2021. The role of protected and unprotected forest remnants for mammal conservation in a megadiverse Neotropical hotspot. Biological Conservation, 259(109173).

Medici, E.P.; Flesher, K.; Beisiegel, B.M.; Keuroghlian, A.; Desbiez, A.L.J.; Gatti, A.; Pontes, A.R.M.; Campos, C.B.; Tófoli, C.F.; Moraes-Jr., E.A.; Azevedo, C.; Pinho, G.M.; Cordeiro, J.L.P.; Santos-Jr., T.S.; Morais, A.A.; Mangini, P.R.; Rodrigues, L.F. \& Almeida, L.B. 2018. Tapirus terrestris (Linnaeus, 1758). In: ICMBio (Ed.). Livro Vermelho da Fauna Brasileira Ameaçada de Extinção: Volume ll - Mamíferos. Brasília, ICMBio. p. 59-68.

Ministério do Meio Ambiente (MMA). 2014a. Portaria № 444, de 17 de dezembro de 2014. Available: https://pesquisa.in.gov.br/imprensa/jsp/visualiza/ index.jsp?jornal=1\&pagina=121\&data=18/12/2014. Access:03/08/2020.

Ministério do Meio Ambiente (MMA). 2014b. Portaria № 445, de 17 de dezembro de 2014. Available: https://pesquisa.in.gov.br/imprensa/jsp/ visualiza/index.jsp?data $=18 / 12 / 2014 \&$ jornal=1\&pagina $=126 \&$ totalAr quivos=144. Access: 03/08/2020.

Miranda, F.R.; Chiarello, A.G.; Röhe, F.; Braga, F.G.; Mourão, G.M.; Braga de Miranda, H.; Moreira da Silva, K.F.; Faria-Côrrea, M.A.; Vaz, S.M. \& Belentani, S.C.S. 2018. Myrmecophaga tridactyla Linnaeus, 1758. In: ICMBio (Ed.). Livro Vermelho da Fauna Brasileira Ameaçada de Extinção: Volume II - Mamiferos. Brasília, ICMBio. p. 40-47.

Morato, R.G.; Beisiegel, B.M.; Ramalho, E.E.; Campos, C.B. \& Boulhosa, R.L.P. 2018. Panthera onca (Linnaeus, 1758). In: ICMBio (Ed.). Livro Vermelho da Fauna Brasileira Ameaçada de Extinção: Volume II - Mamíferos. Brasília, ICMBio. p. 353-357.

Newbold, T.; Scharlemann, J.P.W.; Butchart, S.H.M.; Sekercioglu, Ç.H.; Alkemade, R.; Booth, H. \& Purves, D.W. 2013. Ecological traits affect the response of tropical forest bird species to land-use intensity. Proceedings of the Royal Society, 280(1750): 2012-2131.

Oliveira-Filho, E.C. \& Lima, J.E.F.W. 2002. Potencial de Impacto da Agricultura sobre os Recursos Hídricos na Região do Cerrado. Documentos - EMBRAPA Cerrados, 56: 9-50.
Paula, R.C. \& Boulhosa, L.P. 2015. Caracterização do Conflito: Aspectos Socioculturais e Impactos Econômicos. In: Cavalcanti, S.M.C.; Paula, R.C. \& Gasparini-Morato, R.L. (Eds.). Conflitos com Mamíferos Carnívoros: Uma referência para o manejo e a convivência. Atibaia, ICMBio. p. 11-14.

Paula, R.C.; Rodrigues, F.H.G.; Queirolo, D.; Jorge, R.P.S.; Lemos, F.G. \& Rodrigues, L.A. 2018. Chrysocyon brachyurus (Illiger, 1815). In: ICMBio (Ed.). Livro Vermelho da Fauna Brasileira Ameaçada de Extinção: Volume II - Mamíferos. Brasília, ICMBio. p. 314-320.

Pavanelli, C.S.; Bock, C.L.; Nogueira, C.C.; Nielsen, D.T.B.; Di Dario, F.; Vieira, F.; Neo, F.A.; Gallão, J.E.; Ingenito, L.F.D.; Silva, L.F.D.; Mehanna, M.N.; Vianna, M.A.B.S.; Ribeiro, M.A.R.; Bichuette, M.E.; Volcan, M.V.; Albornoz, P.C.L.; Buckup, P.A.; Amorim, P.F.; Bragança, P.H.N.; Rosa, R.S.; Rocha, R.C.G.A.; Reis, R.E.; Lima, S.M.Q.; Ramos, T.P.A.; Carvalho, T.M.A. \& Costa, W.J.E.M. 2018a. Hypsolebias auratus (Costa \& Nielsen, 2000). In: ICMBio (Ed.). Livro Vermelho da Fauna Brasileira Ameaçada de Extinção: Volume VI - Peixes. Brasília, ICMBio. p. 546-548.

Pavanelli, C.S.; Figueiredo, C.A.A.; Bock, C.L.; Oliveira, C.; Di Dario, F.; Vieira, F.; Neo, F.A.; Gallão, J.E.; Ingenito, L.F.D.; Silva, L.F.D.; Mehanna, M.N.; Bichuette, M.E.; Albornoz, P.C.L.; Buckup, P.A.; Rocha, R.C.G.A.; Reis, R.E.; Santos-Jr., S. \& Ramos, T.P.A. 2018b. Pamphorichthys pertapeh Figueiredo, 2008. In: ICMBio (Ed.). Livro Vermelho da Fauna Brasileira Ameaçada de Extinção: Volume VI - Peixes. Brasília, ICMBio. p. 760-762.

Pignati, W.A.; Lima, F.A.N.S.; Lara, S.S.; Correa, M.L.M.; Barbosa, J.R.; Leão, L.H.C. \& Pignatti, M.G. 2017. Spatial distribution of pesticide use in Brazil: a strategy for Health Surveillance. Ciência \& Saúde Coletiva, 22: 3281-3293.

Prescott, G.W.; Gilroy, J.J.; Haugaasen, T.; Uribe, C.A.M.; Foster, W.A. \& Edwards, D.P. 2016. Managing Neotropical oil palm expansion to retain phylogenetic diversity. Journal of Apllied Ecology, 53(1): 150-158.

Redin, M.; dos Santos, G.F.; Miguel, P.; Denega, G.L.; Lupatini, M.; Doneda, A. \& Souza, E.L. 2011. Impactos da Queima Sobre Atributos Químicos, Físicos e Biológicos do Solo. Ciência Florestal, 21: 381-392.

Ribeiro, J.; Colli, G.R. \& Soares, A.M.V.M. 2020. The anurofauna of a vanishing savanna: the case of the Brazilian Cerrado. Biodiversity and Conservation, 29(6): 1993-2015.

Rodrigues, G.S. \& Irias, L.J.M. 2004. Considerações sobre os Impactos Ambientais da Agricultura Irrigada. Circular Técnica EMBRAPA Meio Ambiente, 7: 1-7.

Rosas, F.C.W. 1994. Biology, conservation and status of the Amazonian manatee Trichechus inunguis. Mammal Review, 24: 49-59.

Santos, S. \& Bueno, S.L.S. 2018. Aegla brevipalma Bond-Buckup \& Santos, 2012. In: ICMBio (Ed.). Livro Vermelho da Fauna Brasileira Ameaçada de Extinção: Volume VI - Invertebrados. Brasília, ICMBio. p. 372-374.

Santos, S.; Bond-Buckup, G.; Buckup, L.; Pérez-Losada, M.; Finley, M. \& Crandall, K.A. 2012. Three new species of Aegla (Anomura) freshwater crabs from the upper Uruguay River Hydrographic Basin in Brazil. Journal of Crustacean Biology, 32(4): 592-540.

Serafini, P.P. 2018. Calidris subruficollis (Vieillot, 1819). In: ICMBio (Ed.). Livro Vermelho da Fauna Brasileira Ameaçada de Extinção: Volume III - Aves. Brasília, ICMBio. p. 154-157.

Silveira, L.F.; Ribeiro, F. \& Lins, L. 2018. Mergus octosetaceus Vieillot, 1817. In: ICMBio (Ed.). Livro Vermelho da Fauna Brasileira Ameaçada de Extinção: Volume III - Aves. Brasília, ICMBio. p. 30-33.

Somenzari, M. 2018. Amazona vinacea (Kuhl, 1820). In: ICMBio (Ed.). Livro Vermelho da Fauna Brasileira Ameaçada de Extinção: Volume III - Aves. Brasília, ICMBio. p. 292-295.

Thomas, R.J.; Quillérou, E. \& Stewart, N. (Eds.). 2013. Economics of Land Degradation Initiative: A Global strategy for sustainable land management. Bonn, ELD Initiative.

Tscharntke, T.; Tylianakis, J.M.; Rand, T.A.; Didham, R.K.; Fahrig, L.; Batáry, P.; Bengtsson, J.; Clough, Y.; Crist, T.0.; Dormann, C.F.; Ewers, R.M.; Fründ, J.; 
Holt, R.D.; Holzschuh, A.; Klein, A.M.; Kleijn, D.; Kremen, C.; Landis, D.A.; Laurance, W.; Lindenmayer, D.; Scherber, C.; Sodhi, N.; Steffan-Dewenter, I.; Thies, C.; Putten, W.H. \& Westphal, C. 2012. Landscape moderation of biodiversity patterns and processes - eight hypotheses. Biological Reviews, 87(3): 661-685.

Vaz-de-Mello, F.Z. \& Nunes, R.V. 2018. Pedaridium hirsutum (Harold, 1859). In: ICMBio (Ed.). Livro Vermelho da Fauna Brasileira Ameaçada de Extinção: Volume VII - Invertebrados. Brasília, ICMBio. p. 279-281.
Wilson, E.0. 1997. A situação atual da diversidade biológica. In: Wilson, E.0. (Org.), Biodiversidade, Rio de Janeiro, Nova Fronteira. p. 3-24.

WorldWildeFund for Nature (WWF). 2015. Unsustainable cattle ranching. Available: http://wwf.panda.org/what we do/where we work/amazon/amazon threats/unsustainable cattle ranching/index.cfm. Access:02/12/2020.

Zenni, R.D.; Dechoum, M.S. \& Ziller, S.R. 2016. Dez anos do informe brasileiro sobre espécies exóticas invasoras: avanços, lacunas e direções futuras. Biotemas, 29: 133-153. 
TABLE S1

List of species threatened by agricultural activities and the impacts to which they are affected.

\begin{tabular}{|c|c|c|c|c|c|c|c|c|c|}
\hline \multirow{2}{*}{ Taxon } & \multicolumn{9}{|c|}{ Impacts } \\
\hline & HR & HF & PI & AP & WS ER & FR & AS & OG TD & RK \\
\hline \multicolumn{10}{|l|}{ AMPHIBIANS } \\
\hline Adelophryne maranguapensis & $x$ & & & & & & & & \\
\hline Agalychnis granulosa & $x$ & $x$ & $x$ & & & & & & \\
\hline Allobates brunneus & $x$ & & & & & & & & \\
\hline Allobates goianus & $x$ & $x$ & $x$ & $x$ & & & & & \\
\hline Aparasphenodon pomba & $x$ & & & & & & & & \\
\hline Bokermannohyla vulcaniae & $x$ & $x$ & $x$ & $x$ & & & & & \\
\hline Bolitoglossa paraensis & $x$ & $x$ & $x$ & & & & & & \\
\hline Chiasmocleis alagoanus & $x$ & $x$ & $x$ & & & & & & \\
\hline Crossodactylus dantei & $x$ & $x$ & & & & & & & \\
\hline Crossodactylus lutzorum & $x$ & & & & & & & & \\
\hline Cycloramphus diringshofeni & $x$ & & & & & & & & \\
\hline Hypsiboas curupi & $x$ & $x$ & & & & & & & \\
\hline Hypsiboas semiguttatus & $x$ & $x$ & $x$ & & & & & & \\
\hline Melanophryniscus cambaraensis & $x$ & $x$ & $x$ & & & & & & \\
\hline Phyllodytes gyrinaethes & $x$ & $x$ & $x$ & & & & & & \\
\hline Physalaemus caete & $x$ & $x$ & $x$ & & & & & & \\
\hline Physalaemus soaresi & $x$ & $x$ & $x$ & & & & & & \\
\hline Proceratophrys moratoi & $x$ & $x$ & $x$ & & $x$ & & & & \\
\hline Proceratophrys palustris & $x$ & & & $x$ & & & & $x$ & \\
\hline Proceratophrys sanctaritae & $x$ & $x$ & $x$ & & $x$ & & & & \\
\hline Thoropa saxatilis & & & & $x$ & & & & & \\
\hline \multicolumn{10}{|l|}{ BIRDS } \\
\hline Acrobatornis fonsecai & $x$ & & & & & & & & \\
\hline Alectrurus tricolor & $x$ & $x$ & & $x$ & $x$ & $x$ & $x$ & $x$ & \\
\hline Amadonastur lacernulatus & $x$ & $x$ & $x$ & & & & & & $x$ \\
\hline Amazona pretrei & $x$ & & & & & & & & \\
\hline Amazona vinacea & & & & & & & & & $x$ \\
\hline Anodorhynchus leari & $\mathrm{x}$ & & & & & & & & $\mathrm{x}$ \\
\hline Anthus nattereri & $x$ & & & $x$ & & $x$ & $x$ & & \\
\hline Anumara forbesi & $x$ & & & $x$ & & & & & \\
\hline Aratinga solstitialis & $x$ & & & & & & & & \\
\hline \multicolumn{10}{|l|}{ Asthenes hudsoni } \\
\hline Attila spadiceus uropygiatus & $x$ & $x$ & $x$ & & & & & & \\
\hline Augastes /umachella & $x$ & & & & & & & & \\
\hline Automolus lammi & $x$ & $x$ & & & & & & & \\
\hline Calidris pusilla & $x$ & & & & $x$ & & & & \\
\hline Calidris subruficollis & $x$ & & & $x$ & & & $x$ & & \\
\hline Campylorhamphus cardosoi & $x$ & & & & & & & & \\
\hline Caryothraustes canadensis frontalis & $\mathrm{x}$ & $x$ & & & & & & & \\
\hline Celeus flavus subflavus & $x$ & & & & & & & & \\
\hline Celeus obrieni & $x$ & $x$ & & & & & & & \\
\hline Cichlopsis leucogenys & $x$ & & & & & & & & \\
\hline Cinclodes espinhacensis & $x$ & & & & & $x$ & & & \\
\hline Circus cinereus & $x$ & & & $x$ & $x$ & & & & \\
\hline Conopophaga lineata cearae & $\mathrm{x}$ & $x$ & & & & & & & \\
\hline Conopophaga melanops nigrifrons & $x$ & $x$ & & & & & & & \\
\hline Coryphaspiza melanotis & $x$ & $x$ & & $x$ & & & $x$ & & \\
\hline Coryphistera alaudina & $x$ & & & & & & & & \\
\hline Cranioleuca muelleri & $\mathrm{x}$ & & & & & & & & \\
\hline Cyanocorax hafferi & $x$ & & & & $x$ & $x$ & & & \\
\hline Cyanopsitta spixii & $x$ & & & & & & & & \\
\hline Dendrexetastes rufigula paraensis & $x$ & & & & & & & & \\
\hline Dendrocincla taunayi & $x$ & $x$ & & & & & & & \\
\hline Dendrocolaptes picumnus transfasciatus & $x$ & & & & & & & & \\
\hline
\end{tabular}

\begin{tabular}{|c|c|c|c|c|c|c|c|c|c|}
\hline \multirow{2}{*}{ Taxon } & \multicolumn{9}{|c|}{ Impacts } \\
\hline & HR & HF & PI & AP & WS ER & FR & & OG TD & RK \\
\hline Discosura langsdorffi langsdorffi & $x$ & $x$ & & & & & & & \\
\hline Eleoscytalopus psychopompus & $x$ & $x$ & & & & & & & \\
\hline Formicivora erythronotos & $x$ & & & & & & & & \\
\hline Geositta poeciloptera & $x$ & $x$ & $x$ & & $x$ & $x$ & $x$ & & \\
\hline Glaucis dohrnii & $x$ & $x$ & & & & & & & \\
\hline Grallaria varia distincta & $x$ & $x$ & & & & & & & \\
\hline Grallaria varia intercedens & $x$ & $x$ & & & & & & & \\
\hline Gubernatrix cristata & & & & & & & & & \\
\hline Hemitriccus furcatus & $x$ & $x$ & & & & & & & \\
\hline Hemitriccus griseipectus naumburgae & $x$ & $x$ & & & & & & & \\
\hline Hemitriccus kaempferi & $x$ & $x$ & & & & & & & \\
\hline Hemitriccus mirandae & $x$ & $x$ & $x$ & & & & & & \\
\hline Herpsilochmus pileatus & $x$ & $x$ & & & & & & & \\
\hline Hydropsalis candicans & $x$ & & & & & $x$ & $x$ & & \\
\hline Lepidocolaptes wagleri & $x$ & $x$ & & & & & & & \\
\hline Lepidothrix iris & $x$ & & & & & $x$ & & & \\
\hline Leptasthenura platensis & $x$ & & & & & $x$ & & & \\
\hline Limnodromus griseus & $x$ & & & & & & & & \\
\hline Lophornis gouldii & $x$ & & & & & & & & \\
\hline Mergus octosetaceus & & & & $x$ & & & & & \\
\hline Merulaxis stresemanni & $x$ & $x$ & $x$ & & & $x$ & & & \\
\hline Momotus momota marcgraviana & $x$ & & & & & & & & \\
\hline Morphnus guianensis & $x$ & & & & & & & & \\
\hline Myrmoderus ruficaudus & & & & & & & & & \\
\hline Myrmotherula snowi & $x$ & $x$ & & & & & & & \\
\hline Myrmotherula klagesi & $x$ & & & & & & & & \\
\hline Nemosia rourei & $x$ & $x$ & & & & & & & \\
\hline Neomorphus squamiger & $x$ & & & & & & & & \\
\hline Neopelma aurifrons & $x$ & & & & & & & & \\
\hline Nothura minor & $x$ & & & & & & & & \\
\hline Ortalis guttata remota & $x$ & & & & & & & & \\
\hline Pauxi mitu & $x$ & $x$ & $x$ & $x$ & & & & & \\
\hline Penelope jacucaca & $x$ & & & & & & & & \\
\hline Penelope ochrogaster & $x$ & & & & & & & & \\
\hline Phaethornis aethopygus & $x$ & $x$ & & & & & & & \\
\hline Phaethornis margarettae camargoi & $x$ & & & & & & & & \\
\hline Phylloscartes beckeri & $x$ & $x$ & $x$ & & & & & & \\
\hline Phylloscartes ceciliae & $x$ & $x$ & & & & & & & \\
\hline Picumnus varzeae & $x$ & & & & & & & & \\
\hline Porzana spiloptera & $x$ & & & & & & & $x$ & \\
\hline Pseudoseisura lophotes & $x$ & & & & & & & $x$ & \\
\hline Pulsatrix perspicillata pulsatrix & & & & & & & & $x$ & \\
\hline Pyriglena atra & $x$ & $x$ & & & & & & & \\
\hline Pyrrhura cruentata & $x$ & & & & & & & & \\
\hline Pyrrhura pfrimeri & $x$ & & & & & & & & $x$ \\
\hline Rhopornis ardesiacus & $x$ & $x$ & $x$ & & & $x$ & & & \\
\hline Schiffornis turdina intermedia & $x$ & $x$ & & & & & & & \\
\hline Sclerurus cearensis & $x$ & $x$ & & & & & & & \\
\hline Scytalopus diamantinensis & $x$ & $x$ & & & & $x$ & & & \\
\hline Scytalopus gonzagai & $x$ & $x$ & & & & $x$ & & & \\
\hline Scytalopus iraiensis & $x$ & $x$ & & $x$ & $x$ & & & & \\
\hline Scytalopus novacapitalis & $x$ & $x$ & & & $x$ & $x$ & & $x$ & \\
\hline Spinus yarrellii & & & & $x$ & & & & & \\
\hline Sporophila beltoni & $x$ & & & & & & & & \\
\hline Sporophila falcirostris & & & & $\mathrm{x}$ & & & & & \\
\hline
\end{tabular}




\begin{tabular}{|c|c|c|c|c|c|c|c|c|c|c|}
\hline \multirow{2}{*}{ Taxon } & \multicolumn{10}{|c|}{ Impacts } \\
\hline & HR & HF & PI & AP & WS & ER & FR & AS & OG TD & RK \\
\hline Sporophila frontalis & & & & $x$ & & & & & & \\
\hline Sporophila hypoxantha & $x$ & & & & & & & & & \\
\hline Sporophila melanogaster & $x$ & & & $x$ & $\mathrm{x}$ & & & $x$ & & \\
\hline Sporophila nigrorufa & $x$ & & & & & & & & & \\
\hline Sporophila palustris & $x$ & & & & $\mathrm{x}$ & & $x$ & $\mathrm{x}$ & $x$ & \\
\hline Sporophila ruficollis & $x$ & & & $x$ & & & $x$ & & & \\
\hline Stigmatura napensis napensis & $x$ & & & & & & & & & \\
\hline Stymphalornis acutirostris & $x$ & $x$ & & & & & & $x$ & $x$ & \\
\hline Synallaxis infuscata & $x$ & $\mathrm{x}$ & & & & & & & & \\
\hline Synallaxis kollari & $x$ & & & & & & & & & \\
\hline Tangara fastuosa & $x$ & $x$ & & & & & & & & \\
\hline Tangara velia signata & $x$ & $\mathrm{x}$ & & & & & & & & \\
\hline Taoniscus nanus & $x$ & $x$ & & & & & $x$ & & & \\
\hline Terenura sicki & $x$ & $\mathrm{x}$ & & & & & & & & \\
\hline Thamnophilus aethiops distans & $x$ & $x$ & & & & & & & & \\
\hline Thamnophilus caerulescens cearensis & $x$ & $x$ & & & & & & & & \\
\hline Tigrisoma fasciatum & & & & $x$ & & & & & & \\
\hline Touit surdus & $x$ & & & & & & & & & \\
\hline Trogon collaris eytoni & $x$ & & & & & & & & & \\
\hline Urubitinga coronata & $x$ & & & $x$ & & & $x$ & & & $x$ \\
\hline Xanthopsar flavus & $x$ & & & $x$ & $\mathrm{x}$ & & $\mathrm{x}$ & & $x$ & \\
\hline Xenops minutus alagoanus & $x$ & $x$ & & & & & & & & \\
\hline Xiphocolaptes falcirostris & $x$ & & & & & & & & & \\
\hline Xiphorhynchus atlanticus & $x$ & & & & & & & & & \\
\hline Xolmis dominicanus & $x$ & & & $x$ & & & $x$ & & $x$ & \\
\hline \multicolumn{11}{|l|}{ INVERTEBRATES } \\
\hline \multicolumn{11}{|l|}{ ANNELIDA } \\
\hline Eunice sebastiani & & & & $x$ & & & & & & \\
\hline \multicolumn{11}{|l|}{ ARACHINIDA } \\
\hline Ananteris infuscata & & & & & & $\mathrm{x}$ & & & & \\
\hline Avicularia diversipes & $x$ & $x$ & $x$ & & & & & & & \\
\hline Avicularia gamba & $x$ & $x$ & & & & & & & & \\
\hline Celaetycheus mungunza & $x$ & $\mathrm{x}$ & & & & & & & & \\
\hline Eukoenenia spelunca & & & & & & $x$ & & & & \\
\hline Eusarcus elinae & & & & & & $\mathrm{x}$ & & & & \\
\hline \multicolumn{11}{|l|}{ Hadrurochactas araripe } \\
\hline landumoema setimapocu & & & & & & $x$ & & & & \\
\hline Metagonia diamantina & & & & & & $x$ & & & & \\
\hline Oligoxystre diamantinensis & $x$ & $x$ & $x$ & & & & & & & \\
\hline Rhopalurus lacrau & & & & & & $\mathrm{x}$ & & & & \\
\hline Spelaeobochica allodentatus & & & & $x$ & & $x$ & & & & \\
\hline Spelaeobochica iuiu & & & & & & $\mathrm{x}$ & & & & \\
\hline Speocera eleonorae & & & & & & $x$ & & & & \\
\hline Typhochlaena seladonia & $x$ & $x$ & $x$ & & & & & & & \\
\hline \multicolumn{11}{|l|}{ CHILOPODA } \\
\hline \multicolumn{11}{|l|}{ Cryptops (Cryptops) spelaeoraptor } \\
\hline \multicolumn{11}{|l|}{ DIPLOPODA } \\
\hline Dioplosternus salvatrix & $x$ & $x$ & & & & & & & & \\
\hline Glomeridesmus spelaeus & & & & & & $x$ & & & & \\
\hline Odontopeltis giganteus & $x$ & $x$ & $x$ & & & & & & & \\
\hline \multicolumn{11}{|l|}{ ENTEROPNEUSTA } \\
\hline Willeyia loya & & & & $x$ & & & & & & \\
\hline \multicolumn{11}{|l|}{ INSECTA } \\
\hline Aceratobasis cornicauda & $x$ & $x$ & & & & & & & & \\
\hline Aceratobasis mourei & $x$ & $x$ & & & & & & & & \\
\hline Actinote quadra & $x$ & & & & & & & & & \\
\hline Adebrotus lugoi & $x$ & $x$ & & & & & & & & \\
\hline Aleuron prominens & $x$ & $\mathrm{x}$ & & & & & & & & \\
\hline Aleuron ypanemae & & & & $x$ & & & & & & \\
\hline Anochetus oriens & $x$ & $x$ & & & & & & & & \\
\hline
\end{tabular}

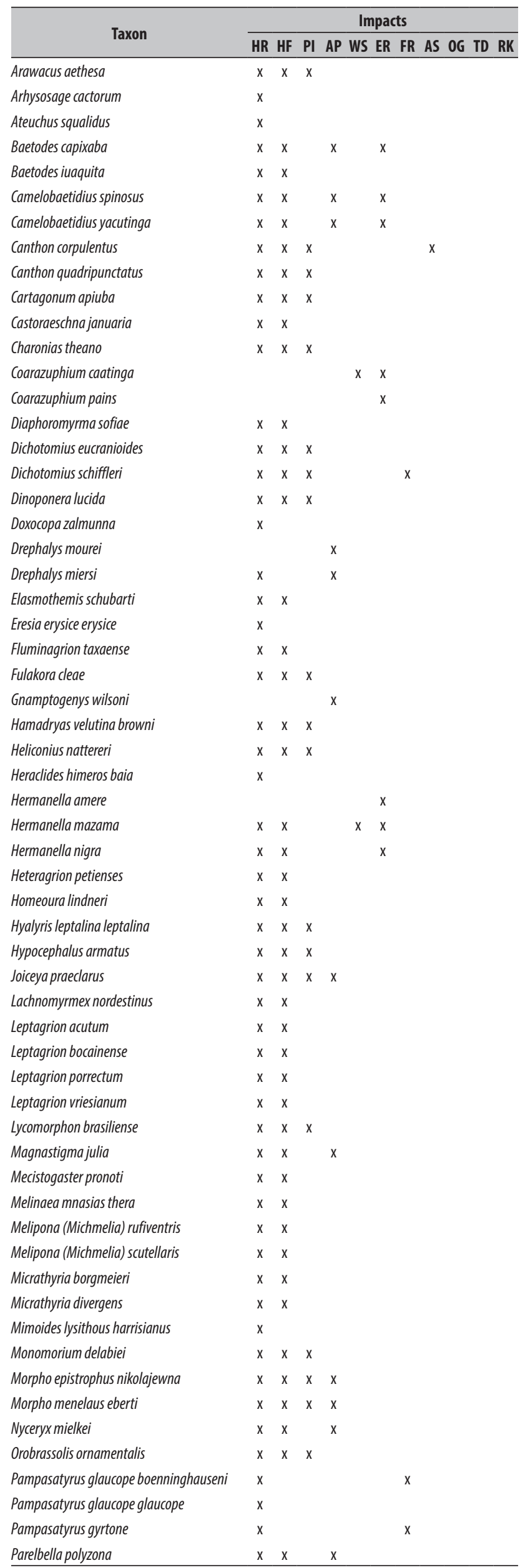




\begin{tabular}{|c|c|c|c|c|c|c|c|}
\hline \multirow{2}{*}{ Taxon } & \multicolumn{7}{|c|}{ Impacts } \\
\hline & HR & HF & PI & AP WS & ER & FR AS OC & G TD RK \\
\hline Parides burchellanus & $x$ & $x$ & & & & $x$ & \\
\hline Parides klagesi & $x$ & $x$ & & & & & \\
\hline Parides panthonus castilhoi & $x$ & $x$ & $x$ & & & & \\
\hline Partamona littoralis & $\mathrm{x}$ & $x$ & & & & & \\
\hline Pedaridium hirsutum & $x$ & & & & & & \\
\hline Phyllocycla bartica & $\mathrm{x}$ & $x$ & & & & & \\
\hline Rhetus belphegor & $x$ & $x$ & & & & $x$ & \\
\hline Rhionaeschna eduardoi & $x$ & $x$ & & & & & \\
\hline Rhopalothrix plaumanni & $x$ & & & $x$ & & & \\
\hline Scada karschina delicata & $x$ & $x$ & $x$ & $x$ & & & \\
\hline Strymon ohausi & $x$ & $x$ & $x$ & $x$ & & & \\
\hline Tithorea harmonia caissara & $x$ & & & & & $\mathrm{x}$ & \\
\hline Zonia zonia diabo & $x$ & & & & & & \\
\hline \multicolumn{8}{|l|}{ MALCACOSTRACA } \\
\hline Aegla brevipalma & & & & $\mathrm{x}$ & $\mathrm{x}$ & & \\
\hline Aegla camargoi & $x$ & $x$ & & $x$ & $x$ & & \\
\hline Aegla franca & $x$ & $x$ & & & $\mathrm{x}$ & & \\
\hline Aegla grisella & $x$ & $x$ & & $x$ & $x$ & & \\
\hline Aegla inermis & $x$ & & & $x$ & $\mathrm{x}$ & & \\
\hline Aegla itacolomiensis & $x$ & & & $x$ & $\mathrm{x}$ & & \\
\hline Aegla lata & & & & $x$ & & $x$ & \\
\hline Aegla leachi & $x$ & $x$ & & & & & \\
\hline Aegla leptodactyla & $x$ & $x$ & & $x$ & $x$ & & \\
\hline Aegla ligulata & $x$ & $x$ & & $x$ & $x$ & & \\
\hline Aegla manuinflata & $x$ & $x$ & & $x$ & & & \\
\hline Aegla oblata & $x$ & $x$ & & $x$ & & & \\
\hline Aegla obstipa & & & & $x$ & $x$ & & \\
\hline Aegla plana & $x$ & $x$ & & & & & \\
\hline Aegla perobae & $x$ & $x$ & $\mathrm{x}$ & $\mathrm{x}$ & & & \\
\hline Aegla pomerana & $x$ & $x$ & & & & & \\
\hline Aegla rossiana & $x$ & $x$ & & & & & \\
\hline Aegla spinipalma & $x$ & $x$ & & $x$ & & & \\
\hline Aegla spinosa & $x$ & $x$ & & & & & \\
\hline Aegla violacea & $\mathrm{x}$ & $x$ & & $\mathrm{x}$ & $\mathrm{x}$ & & \\
\hline \multicolumn{8}{|l|}{ MOLUSCA } \\
\hline Lymnaea rupestris & $x$ & $x$ & & & & & \\
\hline Macrodontes dautzenbergianus & $x$ & & & & & & \\
\hline Megalobulimus cardosoi & $x$ & $x$ & & & & & \\
\hline Olivancillaria contortuplicata & & & & $x$ & & & \\
\hline Olivancillaria teaguei & & & & $x$ & & & \\
\hline Plesiophysa dolichomastix & $x$ & & & & & & \\
\hline Potamolithus karsticus & & & & $x$ & & & \\
\hline Potamolithus troglobius & & & & $x$ & & & \\
\hline Spiripockia punctata & & & & & $\mathrm{x}$ & & \\
\hline Tomigerus (Digerus) gibberulus & $\mathrm{x}$ & $x$ & & & & & \\
\hline \multicolumn{8}{|l|}{ ONYCHOPHORA } \\
\hline Epiperipatus adenocryptus & $x$ & $x$ & & & & & \\
\hline Epiperipatus diadenoproctus & $x$ & $x$ & & & & & \\
\hline Epiperipatus paurognostus & $x$ & $x$ & & & & & \\
\hline \multicolumn{8}{|l|}{ MAMMALS } \\
\hline Alouatta belzebul & $\mathrm{x}$ & $x$ & $\mathrm{x}$ & & & & \\
\hline Alouatta discolor & $x$ & & & & & & \\
\hline Alouatta guariba clamitans & $\mathrm{x}$ & $x$ & & & & & \\
\hline Alouatta guariba guariba & $x$ & $x$ & & & & & \\
\hline Alouatta ululata & $x$ & $x$ & & & & & \\
\hline Ateles chamek & $x$ & $x$ & & & & & \\
\hline Ateles marginatus & $x$ & $x$ & & & & & \\
\hline Blastocerus dichotomus & $x$ & & & $\mathrm{x}$ & & $x$ & $x$ \\
\hline Brachyteles arachnoides & $x$ & $x$ & & & & & \\
\hline Brachyteles hypoxanthus & $\mathrm{x}$ & $x$ & $x$ & & & & \\
\hline
\end{tabular}

\begin{tabular}{|c|c|c|c|c|c|c|c|c|}
\hline \multirow{2}{*}{ Taxon } & \multicolumn{8}{|c|}{ Impacts } \\
\hline & HR & $\mathrm{HF}$ & PI & AP WS ER & FR & AS OG & TD & RK \\
\hline Bradypus torquatus & $\mathrm{x}$ & $x$ & $\mathrm{x}$ & & & & & \\
\hline Callicebus barbarabrownae & $x$ & $x$ & $x$ & & & & & \\
\hline Callicebus coimbrai & $\mathrm{x}$ & $\mathrm{x}$ & & & & & & \\
\hline Callicebus melanochir & $x$ & $\mathrm{x}$ & & & & & & \\
\hline Callicebus personatus & $x$ & $x$ & $x$ & & & & & \\
\hline \multicolumn{9}{|l|}{ Callistomys pictus } \\
\hline Callithrix aurita & $x$ & $x$ & & & & & & \\
\hline Callithrix flaviceps & $x$ & $x$ & & & & & & \\
\hline Cebus kaapori & $x$ & $x$ & & & $x$ & & & \\
\hline Cerradomys goytaca & $x$ & & & & & & & \\
\hline Chiropotes satanas & $x$ & $x$ & & & & & & \\
\hline Chiropotes utahickae & $x$ & $x$ & & & & & & \\
\hline Chrysocyon brachyurus & $x$ & & & & & & & $x$ \\
\hline Coendou speratus & $x$ & $x$ & $x$ & & & & & \\
\hline Ctenomys lami & $x$ & $x$ & $x$ & & & & & \\
\hline Eptesicus taddeii & $\mathrm{x}$ & $x$ & & & & & & \\
\hline Glyphonycteris behnii & $x$ & $x$ & & & & & & \\
\hline Gyldenstolpia planaltensis & $x$ & & & & & & & \\
\hline Kerodon acrobata & $x$ & & & & & & & \\
\hline Lagothrix cana cana & $\mathrm{x}$ & $x$ & & & & & & \\
\hline Lonchophylla dekeyseri & $x$ & $x$ & & & & & & \\
\hline Leontopithecus chrysomelas & $x$ & $x$ & & & & & & \\
\hline Leontopithecus chrysopygus & $x$ & $x$ & $x$ & & & & & \\
\hline Leopardus colocolo & $\mathrm{x}$ & $\mathrm{x}$ & & & $\mathrm{x}$ & & & $\mathrm{x}$ \\
\hline Leopardus geoffroyi & & & & & & & & $\mathrm{x}$ \\
\hline Leopardus guttulus & $x$ & $x$ & & & & & & $\mathrm{x}$ \\
\hline Leopardus tigrinus & $\mathrm{x}$ & $x$ & & & & & & $\mathrm{x}$ \\
\hline Leopardus wiedii & $\mathrm{x}$ & $x$ & & & & & & $\mathrm{x}$ \\
\hline Lycalopex vetulus & $x$ & $x$ & & & & & & $\mathrm{x}$ \\
\hline Marmosops paulensis & $x$ & $x$ & & & & & & \\
\hline Mazama bororo & $\mathrm{x}$ & $x$ & & & & & & \\
\hline Mazamanana & $x$ & $x$ & & $x$ & & & $x$ & \\
\hline Mico rondoni & $\mathrm{x}$ & $x$ & & & & & & \\
\hline Myrmecophaga tridactyla & $x$ & $x$ & & $x$ & & & & \\
\hline Ozotoceros bezoarticus bezoarticus & $\mathrm{x}$ & $\mathrm{x}$ & & & & $\mathrm{x}$ & $\mathrm{x}$ & \\
\hline Ozotoceros bezoarticus leucogaster & $\mathrm{x}$ & $\mathrm{x}$ & & & & $\mathrm{x}$ & $\mathrm{x}$ & \\
\hline Panthera onca & $x$ & $x$ & & & & & & $\mathrm{x}$ \\
\hline Phyllomys brasiliensis & $\mathrm{x}$ & & & & & & & \\
\hline Phyllomys unicolor & $\mathrm{x}$ & & & & & & & \\
\hline Priodontes maximus & $x$ & $x$ & & & & & & \\
\hline Pteronura brasiliensis & & & & $x$ & & & & \\
\hline Puma concolor & $\mathrm{x}$ & $\mathrm{x}$ & & & $\mathrm{x}$ & & & $\mathrm{x}$ \\
\hline Puma yagouaroundi & $\mathrm{x}$ & $x$ & & & $\mathrm{x}$ & & & $\mathrm{x}$ \\
\hline Rhipidomys cariri & $\mathrm{x}$ & & & $\mathrm{x}$ & & & & \\
\hline Rhipidomys tribei & $x$ & $x$ & & & & & & \\
\hline Saguinus niger & $\mathrm{x}$ & $x$ & & & & & & \\
\hline Sapajus cay & $\mathrm{x}$ & $x$ & & & & & & \\
\hline Sapajus flavius & $x$ & $x$ & $\mathrm{x}$ & & & & & \\
\hline Sapajus robustus & $\mathrm{x}$ & $x$ & & & & & & \\
\hline Sapajus xanthosternos & $x$ & $x$ & & & & & & \\
\hline Tapirus terrestris & $\mathrm{x}$ & $\mathrm{x}$ & & & & & $\mathrm{x}$ & \\
\hline Tayassu pecari & $\mathrm{x}$ & $\mathrm{x}$ & & & $\mathrm{x}$ & $\mathrm{x}$ & $\mathrm{x}$ & \\
\hline Thalpomys cerradensis & $\mathrm{x}$ & & & & & & & \\
\hline Thylamys macrurus & $x$ & & & & & & & \\
\hline Thylamys velutinus & $\mathrm{x}$ & & & & & & & \\
\hline Tolypeutes tricinctus & $\mathrm{x}$ & & & & & & & \\
\hline Trichechus manatus & $\mathrm{x}$ & & & & & & & \\
\hline Trichechus inunguis & & & & $x$ & & & & \\
\hline Trinomys eliasi & $\mathrm{x}$ & $\mathrm{x}$ & & & & & & \\
\hline Trinomys mirapitanga & $\mathrm{x}$ & $\mathrm{x}$ & & & & & & \\
\hline
\end{tabular}




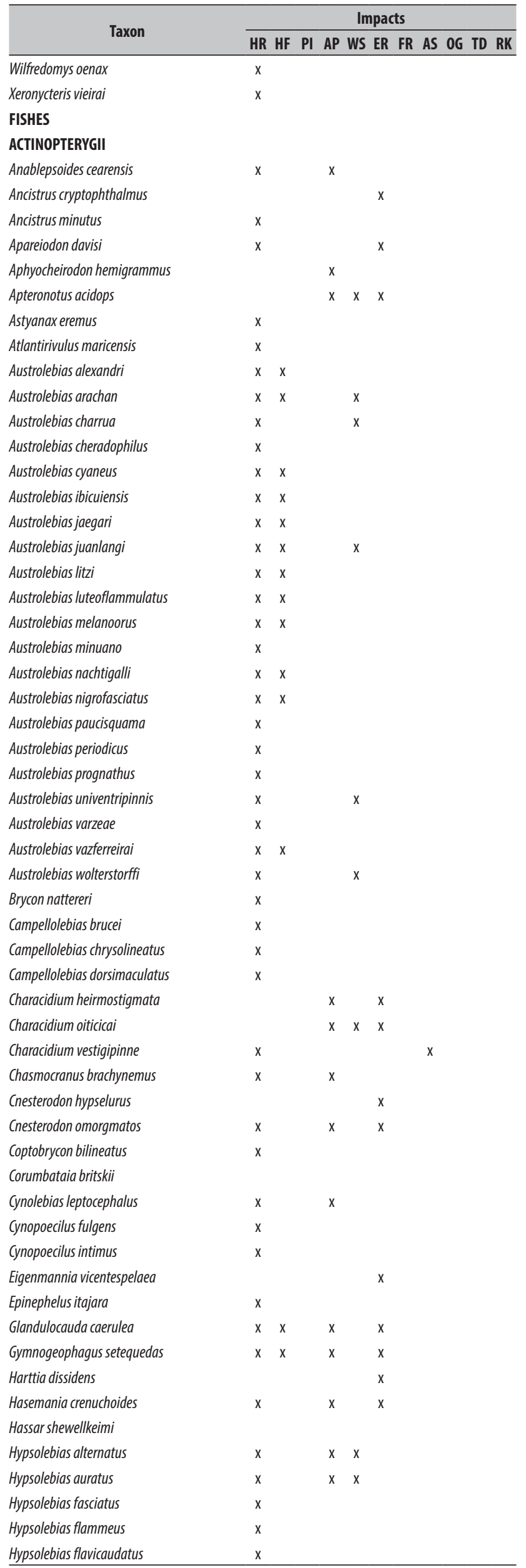

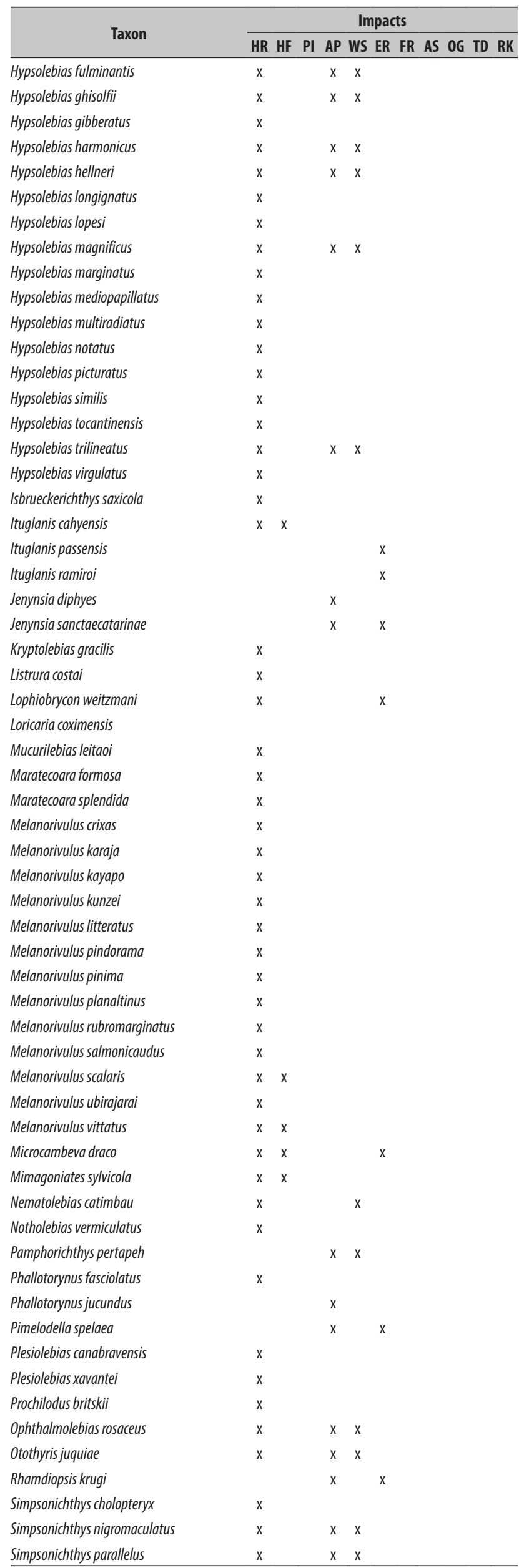




\section{Taxon}

Simpsonichthys punctulatus

Simpsonichthys zonatus

Spintherobolus leptoura

Stygichthys typhlops

Teleocichla centisquama

Trichogenes claviger

Trichomycterus dali

Trichomycterus rubbioli

Trichomycterus triguttatus

Trichomycterus tropeiro

Xenurolebias myersi

\section{ELASMOBRANCHII}

Paratrygon aiereba

\section{REPTILES}

Ameiva parecis

Amerotyphlops amoipira

Amerotyphlops paucisquamus

Amerotyphlops yonenagae

Amphisbaena arda

Amphisbaena frontalis

Amphisbaena supernumeraria

Amphisbaena uroxena

Apostolepis arenaria

Apostolepis gaboi

Apostolepis quirogai

Apostolepis serrana

Apostolepis striata

Atractus caete

Atractus hoogmoedi

Atractus ronnie

Atractus thalesdelemai

Bachia didactyla

Brasiliscincus caissara

Bothrops muriciensis

Bothrops pirajai
Impacts

HR HF PI AP WS ER FR AS OG TD RK

$\mathrm{x}$

$x$

$\mathrm{x}$

$x$

$x \quad x$

$x \quad x$

$\mathrm{x}$

$\mathrm{x}$

$x \quad x$

$x$

$\mathrm{x}$

$x \quad x$

$\mathrm{x}$

$x \quad x \quad x$

$x$

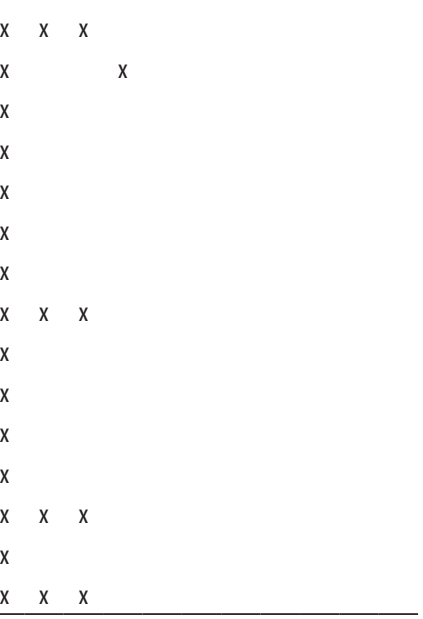

\begin{tabular}{|c|c|c|c|c|c|c|}
\hline \multirow{2}{*}{ Taxon } & \multicolumn{6}{|c|}{ Impacts } \\
\hline & HR & HF & PI & AP WS ER & FR AS & OG TD RI \\
\hline Calamodontophis paucidens & $x$ & $x$ & $x$ & & & \\
\hline Calamodontophis ronaldoi & $x$ & & & $x$ & & \\
\hline Colobodactylus dalcyanus & $x$ & $\mathrm{x}$ & $x$ & & & \\
\hline Contomastix vacariensis & $x$ & $\mathrm{x}$ & $x$ & & $\mathrm{x}$ & \\
\hline Dactyloa nasofrontalis & $x$ & & & & & \\
\hline Dactyloa pseudotigrina & $x$ & & & & & \\
\hline Ditaxodon taeniatus & $x$ & & & & & \\
\hline Echinanthera cephalomaculata & $x$ & $x$ & & & & \\
\hline Enyalius erythroceneus & $x$ & $\mathrm{x}$ & & & & \\
\hline Eurolophosaurus amathites & $x$ & & & & & \\
\hline Heterodactylus /undii & $x$ & $\mathrm{x}$ & $x$ & & & \\
\hline Heterodactylus septentrionalis & $x$ & & & $x$ & & \\
\hline Homonota uruguayensis & $x$ & $x$ & $x$ & & & \\
\hline Hydrodynastes melanogigas & $x$ & & & & & \\
\hline Kentropyx vanzoi & $x$ & & & & & \\
\hline Leposoma baturitensis & $x$ & $\mathrm{x}$ & & & & \\
\hline Leposoma nanodactylus & $x$ & $x$ & & & & \\
\hline Leposomapuk & $x$ & $x$ & $x$ & & & \\
\hline Leposternon kisteumacheri & $x$ & $\mathrm{x}$ & & & & \\
\hline Liolaemus arambarensis & $x$ & $\mathrm{x}$ & $x$ & & & \\
\hline Liolaemus occipitalis & $x$ & $\mathrm{x}$ & & & & \\
\hline Phalotris multipunctatus & $x$ & & & & & \\
\hline Philodryas livida & $x$ & & & & & \\
\hline Placosoma cipoense & $x$ & $\mathrm{x}$ & & & $\mathrm{x}$ & $x$ \\
\hline Rodriguesophis chui & $x$ & & & & & \\
\hline Rodriguesophis scriptorcibatus & $x$ & & & & & \\
\hline Stenocercus azureus & $x$ & & & & & \\
\hline Stenocercus dumerilii & $x$ & & & & & \\
\hline Tropidurus erythrocephalus & $x$ & & & & & \\
\hline Tropidurus hygomi & $x$ & $\mathrm{x}$ & & & & \\
\hline Tropidophis grapiuna & $x$ & $x$ & $x$ & & & \\
\hline Total & 450 & 239 & 69 & 1004051 & 3316 & $\begin{array}{lll}11 & 6 & 15\end{array}$ \\
\hline
\end{tabular}

$\mathrm{HR}=$ Habitat Reduction; $\mathrm{HF}=$ Habitat Fragmentation; $\mathrm{PI}=$ Population Isolation; $\mathrm{AP}=$ Agricultural Pollution; WS = Changes to Water Structures; $E R=$ Erosion; $F R=$ Fire; $A S=$ Introduction Invasive Alien Species; $0 \mathrm{G}=$ Overgrazing; $\mathrm{TD}=$ Transmission Diseases; RK = Retaliatory Killing. 